\title{
Alternatif Bir Gastronomi Tarihi İncelemesi: Resim Sanatında Yemek Hazırlıklart ve Mutfak Sahneleri
}

\author{
An Alternative Analysis on History of Kitchens Through Food Preparation and \\ Kitchen Scenes in the Art of Painting
}

Defne AKDENIZ*

$\ddot{O} Z$

Bu çalışma yemek hazırlıklarının ve mutfakların konu edildiği resim sanatı örnekleri aracılığıyla, gastronomi alanındaki yazını zenginleştirmeyi amaçlamaktadır. Insanın yemekle olan sıkı ilişkisinin en açık biçimde görüldüğü yerlerden biri de yiyecek hazırlıklarının yapıldı̆̆ mutfaklardır. Mutfaklar, özellikle Avrupa resim sanatı örneklerinde sıklıkla ele alınmıştır. Araştırma alanını 16. ve 19.yy arası olarak belirleyen bu çalışma, döneminin mutfaklarını en iyi temsil ettiğini düşündüğ̈̈ toplam 12 tabloyu ayrıntıll olarak incelemiştir. Erken dönem resim örneklerinde ön planda meşakkatli işlerin görüldü̈̆̈̈ yemek hazırlı sahneleri arka planda kendilerine zltlı oluşturacak kutsal sahnelerle birlikte verilmiştir. Yaşanan toplumsal değişmelerle birlikte resim sanatında görülen yemek hazırlı̆̆ ve mutfak sahneleri de değişmeye başlamış, kullanılan gereçler farklılaşmış, mutfakta yapılan işler daha az zahmet gerektirmeye başlamıştır. Mutfak resimlerinin kasvet verici görüntüsü 19.yy'dan itibaren büyük bir değişim göstermiş ve artık yemek pişirmek kaba bir iş olmaktan uzaklaşarak zarafet gerektiren bir sanat halini almıştır.

ANAHTAR KELIMELER

Yemek Hazırlıklarl, Mutfaklar, Resim Sanat,, Gastronomi Tarihi

\begin{abstract}
This study aims to enrich the literature on gastronomy, through examples of painting in which culinary preparations and kitchens are depicted. The kitchens are one of the venues where the close relationship between human and food is visibly clear. The kitchens are frequently reflected in European painting. Limiting its research area as the kitchens between the 16th and 19th centuries, this study examines 12 paintings in detail that are considered to be relevant representations of their era's kitchen. In early examples tough food preparation process and wide variety of foodstuffs in the foreground were given together with the sacred scenes in the background. In time food preparation and kitchen scenes have started to change. The tools used in the kitchen have differentiated and the labor has started to require less effort. The bleak image of kitchen paintings has changed from 19th century onwards, and cooking has become an art created by specialized staff.
\end{abstract}

KEYWORDS

Food Preparation, Kitchen, Art of Painting, Gastronomy History

\begin{tabular}{|c|c|c|}
\hline \multicolumn{2}{|r|}{$\begin{array}{c}\text { Makale Geliş Tarihi / Submission Date } \\
\text { 19.04.2019 }\end{array}$} & $\begin{array}{l}\text { Makale Kabul Tarihi / Date of Acceptance } \\
\text { 20.06.2019 }\end{array}$ \\
\hline Atıf & $\begin{array}{l}\text { Akdeniz, D. (2019). Alternatif Bir Ga } \\
\text { Sahneleri. Selçuk Üniversitesi Sosyal B }\end{array}$ & $\begin{array}{l}\text { hesi: Resim Sanatında Yemek Hazırlıkları Ve Mutfak } \\
\text { kulu Dergisi, } 22 \text { (2), 490-507. }\end{array}$ \\
\hline
\end{tabular}

\footnotetext{
* Dr. Öğr. Üyesi, Çanakkale Onsekiz Mart Üniversitesi, Ayvacık Meslek Yüksekokulu, defneakdeniz@ comu.edu.tr, ORCID: 0000-0001-8572-5438
} 


\section{GíRiş}

Günümüzde yaşam alanlarının açık ya da kapalı bir bölümü olarak algılanan ve Türk Dil Kurumu sözlüğünde 'yemek pişirilen yer, aş damı' olarak tanımlanan "mutfak" terimi yalnızca bu sözlük anlamıyla kullanılmamaktadır. "Mutfak" zamanla fiziksel bir mekânı tanımlamanın dışına çıkarak, yeme kültürü, yeme alışkanlıkları, pişirme yöntemleri ve yemeklerin kendisini ifade eden geniş bir kavram haline gelmiştir. Örneğin bugün "Fransız Mutfağı" dendiğinde Fransa'da bir evin yahut bir restoranın bir mimar tarafindan tasarlanmış bölümü akla nadiren gelmektedir. Akla gelen şey genellikle Fransız yemekleri, soslar, tatlılar, sofralar, aşçılardır. Bir coğrafi bölgenin ya da bir ulusun genel yemek kültürü üzerine yazılmış pek çok kaynak mevcuttur. Aynı örnek üzerinden gidilecek olursa "Fransız Mutfăğ" anahtar kelimesiyle yapılacak bir literatür taramasında sayısız kaynakla karşılaşılmaktadır (Grolier, 2005: Holland, 2016: Korkutata, 2013: Larousse Gastronomique). Bu örneklerde de genellikle Fransız mutfağının bir tarihçesi, genel özellikleri, öğünler ve alışkanlıklar, bölgelere göre farklılaşmalar ve yemek tarifleri verilmektedir.

$\mathrm{Bu}$ çalışma "mutfak" kavramını yazında nadiren ele alınan biçimiyle yani bir fiziksel mekan olarak ele almaktadır. Dar anlamıyla mutfakları, bir diğer deyişle yemek pişirilen yerleri incelemektedir. Ancak burada bir noktaya dikkat çekmek gerekmektedir: Dar anlam dendiğinde konunun da kapsam olarak dar olacağ 1 düşünülmemelidir. Fiziksel mekân olarak mutfaklar ve tarihçesi, geçirdiği dönüşümler, fiziksel donanımları, sınıflar arası farklılaşma göstergesi olması, bir güç alanı olarak sembolik bir yeri ifade etmesi, fiziksel tasarımı, kullanılan ekipmanlar gibi unsurlar düşünüldüğünde oldukça geniş bir araştırma konusudur. Farklı coğrafyalara ve farklı uluslara ait farklı ve çok çeşitli mutfak yapıları (Ortadoğu, Avrupa, Afrika, Çin, Türk vb.) ele alındığında ise konu başlı başına farklı bir araştırma alanıdır. Bir diğer deyişle, yazında yemek ve mutfak tarihi üzerine sayısız araştırma bulunmaktadır (Akbaba ve Çetinkaya, 2018; Bober, 2014; Civitello, 2008; Crowther, 2013; Delemen, 2003; Freedman, 2008; Goody, 2013; Grieco, 2009; Gürsoy, 2013; Gürsoy, 2014; Iş1n, 2018; Kiple, 2010; Kiple ve Ornelas, 1999; Montanari, 1995; Toussaint-Samat, 1992; Soyer, 1977; Standage, 2016). Ancak mutfakları fiziksel bir mekan olarak tek başına ele alan çalışmalara görece nadiren rastlanmaktadır (Bendiner, 2004; İren Boynudelik ve Önel Kurt; 2018; Malaguzzi, 2008; Tez, 2012).

Belirtilen nedenler dolayısıyla bu çalışma, araştırmacılar tarafindan oldukça ihmal edilmiş bir alanı aydınlatmak amacıyla mutfakların fiziksel bir mekan olarak geçirdikleri değişimleri takip etmiştir. Bunu yaparken birincil amacı mutfaklar olan (İren Boynudelik ve Önel Kurt; 2018; Malaguzzi, 2008) ve birincil amacı mutfaklar olmayıp da mutfakların fiziksel yapılarıyla ilgili satır aralarında bilgiler veren (Akdeniz Ay, 2017; Barnes ve Rose, 2002; Bendiner, 2004; Freedman, 2008; Grieco, 2009; Riley, 2015; Sullivan, 1999) kaynaklardan faydalanılmıştır. Bahsedilen kaynakları yeterli bulmayan bu çalışma, konunun daha sistematik ve bilimsel açıdan ele alınabilmesi için resim sanatına başvurmuştur. Yaratıldığ 1 döneme tanıklık eden resim örnekleri amacıyla, konuya yeni ve farklı bir bakış açısı getirilmiş, analiz boyutu çeşitlendirilmiş ve belki de en önemlisi metin aralarında okuduğumuz mutfaklara dair daha somut ve daha derinlemesine tespitler yapılmıştır. Farklı bir disiplinden destek alan bu çalışma böylelikle akademik yeterliliğini artırmay1 hedeflemiştir. Bu kapsamda çalışma toplam 12 resim sanatı örneğine yer vermiştir. Çalışmada ele alınan resimler seçilirken eserlerin dönemine ve bölgesine sadık kalmasına, tarihsel gerçeklikleri temsil edebilmesine ve mutfaklar üzerine mevcut yazını çeşitlendirebilme ve zenginleştirebilme potansiyeline dikkat edilmiştir.

Bahsedilen geniş araştırma çerçevesini buraya not düşen bu çalışma, zaman kısıtı dolayısıyla inceleme alanını daraltmayı uygun görmüştür. Bunun nedeni de mutfakları doğrudan ya da dolaylı olarak tasvir eden resim sanatı örneklerine özellikle 16.yüzyıldan sonra daha sık rastlanmasıdır. Özellikle Rönesans döneminde sanatın din etkisinden uzaklaşmasıyla başlayan zaman diliminde, gündelik hayata dair resimler yapılmaya başlanmıştır (Akdeniz, 2018; Buchholz ve diğ, 2012; Farthing, 2014; Grombich, 2013). Böylelikle mutfaklar resim sanatında görece daha çok yer bulmaya başlamıştır. Yapıldığı dönemin mutfaklarına (konumu, kapladığı alan, tasarımı, kullanılan ekipmanlar, mutfakta çalışanlar vb.) tanıklık eden bu resim sanatı örnekleriyle mutfaklar fiziksel bir mekan olarak mercek altına alınmıştır. Çalışma öncelikle mutfağın kısa bir tarihini vermiş, resim sanatında gördüğ̈̈müz mutfak temsilleri üzerine bilgiler toplamış, inceleme alanı olarak benimsediği dönemin yapısı hakkında bilgi vermiş ve daha sonra da resim sanatı aracıllı̆ıyla mutfakları detaylarıyla incelemiştir.

\section{MUTFAĞIN KISA TARIHII}

Daha önce de belirtildiği gibi 'mutfak' dendiği zaman akla gelen ilk şeylerin genellikle bölgeye, topluluğa veya döneme özgü yeme içme öğeleri olması bu kelimenin kullanım alanının genişlemesinden kaynaklanır. Örneğin Ortaçağ İtalyan Mutfağını ele alan bir çalışmanın Ortaçağ İtalyası'nda yaşayan insanların (zengin veya fakir) hangi yiyeceklerle beslendiklerini, yiyecekleri nasıl hazırladıklarını, gıdayı hangi miktarlarda ve nasıl tükettiklerini incelemesi beklenir. O dönemde ve coğrafyada bir eve, hana, tavernaya ya da saraya ait bir 
mutfağın fiziksel tasarımı, mutfağın evin içindeki konumu, mutfakta kullanılan ekipmanlar, çalışanlar gibi unsurlar nadiren ele alınır. Ancak mutfakların fiziksel bir mekan olarak yazında ele alınmayışı mutfaklara önem verilmediği anlamına gelmez. Aksine insanın ateşi bulmasıyla ve gıdaları pişirmeye başlamasıyla insan ilk ilkel mutfakları oluşturmaya başlamış ve yaşamını ateşin etrafında şekillendirmeye başlamıştır. Ateşi henüz kontrol altına alamamış avcı durumundaki insansı atalarımızın bile yakaladıkları avlara ait beyin, dil ve diğer iç organları parçalamak ve paylaşmak amacıyla avlarını kasaplık işlerine ayırdıkları özel noktalara taşıdıkları bilinmektedir (Picq ve diğ, 2016:38).

İnsanoğlu ateşi keşfedip kontrol altına aldıktan sonra onu yemek pişirmede, 1sınmada, çanak-çömlek yapımında, damıtma işlemlerinde, metalleri eritmede kullanmıştır. Şekillendirdiği toprağı pişirerek çanakçömlek yapmaya başlayan insanoğlu giderek ilerlettiği yapım teknolojisi sayesinde farklı şekil ve ebatlarda, farklı kullanımlara imkan sağlayan mutfak gereçleri yapmaya başlamıştır. Öncelikle toprağı kullanarak başladığı bu yolda daha sonra metalleri eritmeye başlamış böylelikle daha dayanıklı pişirme ve muhafaza ekipmanları tasarlamıştır (Tez, 2012:107).

Avrupa mutfaklarında yemek pişirmenin gelişim çizgisinde önceleri açık ocak ve şöminelerin bulunduğu bölümler görülür. Daha sonra odun sobasını görülmeye başlanan yemek pişirme alanlarında kuzineler ortaya çıkar. Sanayi devrimiyle birlikte gelen ileri teknolojiler ile birlikte gazla ve elektrikle çalışan ocaklar mutfaklar kullanılmaya başlamıştır (Tez, 2012:107-108).

Evdeki yaşam alanından uzaklaşmamak kaydıyla yemek pişirmek için ayrı bir bölümün yapılandırıldığı mutfak benzeri yerlere ilk olarak Ürdün Vadisi’ndeki Eriha (M.Ö. 7.700) ve Türkiye'deki Çatalhöyük (M.Ö. 7.000) Neolitik yerleşim alanlarında rastlanmıştır. Bu dönemde pişirmek amacıyla henüz ateşe çok dayanıklı olmayan çömlek kaplar, deri tulumlar ve içi boşaltılmış su kabakları kullanılır. Yiyecekler genellikle doğrudan çıplak ateş üzerinde (örn. etler) ve sıcak taşların üzerinde (örn. ekmek) pişirilir. İlerleyen yıllarda Mezopotamya'da evden ayrı bir bölümde, yerden biraz yüksekte kerpiçten yapılmış ocaklar görülür. Bu pişirme ekipmanı günümüzde pek çok ülkede farklı isimlerle ve ülkemizde de "tandır" ismiyle halen kullanılmaktadır (Tez, 2012:108).

Mutfak yapıları ve araç gereçlerinin 21.yy mutfak kültürüne etkilerini inceleyen bir çalışmanın (Aksoy ve Çetin, 2018) oldukça ilgi çekici bulgularına göre bugün Çatalhöyük bölgesi sakinlerine ait mutfaklarının halen Neolitik dönemde yaşamış atalarının mutfak kültürüne dair izler taşıdığı görülmüştür. Zaman içinde değişikliklere uğramış olsa da Neolitik Çatalhöyük'te ortaya çıkarılan alçak tabanlı fırınların biçimsel olarak aynı kaldığı ve yapımında materyal olarak hala balçık kullanıldığı görülmektedir. Aynı şekilde 'tandır'ın da halen yöre halkı için günlük yaşamın önemli bir parçası olduğu saptanmıştır. Çatalhöyük halkının tarıma geçmesiyle birlikte yiyeceklerini saklamak ve depolamak amaciyla ev düzenlerine ekledikleri kilerler de benzer kullanım amacıyla 'bitek' adı altında varlığını sürdürmektedir. Tüm bu bilgiler günümüz mutfak yapısının ve kültürünün anlaşılmasında tarihe başvurmanın önemini ortaya koymakta ve fiziksel bir mekan olarak mutfakların tarihsel süreçteki izini sürmeyi amaçlayan bu çalışmanın gerekliliğine örnek teşkil etmektedir.

Antik Yunan dönemine gelindiğinde evlerin ayrı bir mutfağı olmadığı görülür. Bu dönemde yemek hazırlamanın kutsal unsurları olduğu düşünülür ve bu nedenle yemek hazırlıkları ortak açık alanlarda yapılırdı (Malaguzzi, 2008:73). Varlıklı kesime ait ayrı mutfakların ortaya çıkması da bu döneme rastlar. Antik Yunan'da varlıklı kesimin mutfağı, genellikle ortak avluda kurulan açık hava mutfağından farklı olarak evin içindedir. Eski Roma'da da Antik Yunan'da olduğu gibi alt sınıfların evinde mutfak bulunmaz. Romalılar genellikle yemek hazırlamak ve pişirmek için merkezi ortak mutfak ve firınları kullanırdı (Tez, 2012). M.S. 3.yy'dan itibaren Roma mutfaklarında modern mutfaklarınkine benzer ekipmanlar kullanılırdı (Malaguzzi, 2012:73).

Ortaçağ Avrupa'sında mutfak ortak yaşam alanında bulunurdu. Şöminenin bulunmasıyla ocağın yeri, evin ortasından duvar kenarlarına taşındı. Aynı zamanda evi ısıtma görevi gören mutfaklar, bu işlevini yavaş yavaş yitirdi. Açık ateşin yerini duvarları çini kaplı ocaklar almaya başladı. Çömleklerin yerini demir, tunç veya bakırdan yapılma kazanlar aldı. Bu kazanlar ya kendinden üçayaklı olur ve yerde durur ya da bir zincirle asılarak ateşin üstünde havada dururdu (Tez, 2012:108-115).

Ortaçağ sonlarının Avrupa'sında en yaygın kullanılan pişirme yöntemleri haşlamak, firında pişirmek, kavurmak, kızartmak ve ızgarada pişirmekti. Haşlama işlemi bir ateşin üzerine asılan bir tencerede yapılırdı. Söz konusu yemek varlıklı bir ailenin konağında yapılıyorsa bu işlem büyük kazanlarda yapılırdı. Fırında pişirme, kavurma ve kızartma işlemleri haşlamaya göre daha büyük uğraş gerektirirdi. Büyük konakların hepsinde fırın yoktu ve bazen yemekleri başka firınlarda para ile pişirtmek gerekirdi. Kavurma yöntemi ise başlı başına bir statü göstergesiydi. Bu işlem için bol miktarda kaliteli ete ve bol yağa (tavalardan damlarken toplanan ya da kazanlardan sıyrılan yağlar da dâhil olmak üzere bol içyağına) gereksinim duyulurdu. Bu yağlar 
oldukça pahalı olduğundan kavurma yeme ayrıcalığı genellikle üst mertebedeki kişiler ile sınırlıydı (Woolgar, 2008).

Ortaçağ Avrupa'sında mutfaklar yangın riskini en aza indirmek amacıyla genellikle ayrı bir binada bulunurdu. Yangın riskinden dolayı firınlar, bira imalathaneleri, kümes hayvanlarının yolunduğu haşlama daireleri ve bulaşıkhaneler de ana binalardan ayrıyd. Ekmek, süt ürünleri ve sofra gereçlerini koymak için kilerlere gerek vardı. Et ve balıkların tutulduğu kilerde ayrıca kuru ürünler saklanır ve yaş ürünler işlenirdi. Gıdaların en taze halleriyle yenilmesini sağlamak için, hayvanlar ve balıklar olabildiğince uzun süre canlı tutulurdu (Woolgar, 2008; 184). Gıdaları soğuk ve taze tutmada yaşanan zorluklar yüzünden başvurulan bu uygulama canlı av hayvanlarının ve balıkların mutfaklarda sıklıkla görülmesinin (örn. Resim 5) nedenini açılar niteliktedir.

14. ve 15. yüzyıllarda Avrupa'da barut, pusula ve matbaanın icadıyla birlikte Amerika, Afrika ve Asya'da pek çok yeni bölge keşfedildi. Bu yüzyıllarda Protestan ve Katolik kiliseleri arasındaki din savaşları dolayısıyla devletlerin ve ideolojilerin rekabeti başladı. Tüm bu gelişmeler modern çağ Avrupa'sının yemek kültürünü de değiştirdi. Matbaa sayesinde yemek kitapları, beslenme kılavuzları ve hatta gastronomi felsefesiyle ilgili kitaplar basıldı. Pusula ve barutun icadıyla kolaylaşan denizaşırı yolculuklar sonucunda Avrupalılar keşfettikleri yeni dünyalardan getirdikleri pek çok yeni gıdayla tanıştı. Öte yandan imparatorluklar içinde güçlenmeye başlayan ulus-devlet kavramı, ulusal mutfaklar aracılığıyla ulusal bir kimlik inşasına ön ayak oldu. Ancak ulusal mutfağın devamlılığını sağlamak oldukça zordu çünkü mutfak kültürü devrimsel değişimler karşısında sürekli parçalanıyordu. Bir yanda Avrupalı elitlerin paylaştığı yeni ve kozmopolit zevkler, diğer yanda rakip ülke mutfakları karşısında vurgulanmaya çalışılan farklılıklar ve üstünlükler, karmaşık, bölünmüş ve hatta sıkışmış bir mutfak kültürüne geçişe sebep oluyordu. Hümanizmin rafine düşünsel kültürüyle birlikte klasik antik çağın mutfak ve beslenme mirasını sürdürmeye ve canlandırmaya çalışan mutfak, yeni gıdaların ve yeni pişirme tekniklerinin modern etkisine maruz kalıyordu. (Cowan, 2008).

Rönesans döneminin hümanist yazarları antik çağın mutfağını belgeleme ve koruma çabasına yönelmişti. Yaptıkları çalışmalarda hangi gıdaların yenilmesi ya da yenilmemesi, nasıl yenilmesi, ne kadar sıklıkla ve hangi bileşimlerle (sos, baharat vb.) yenilmesi gerektiğini tartışmaya açmışlardı. Her ne kadar bu çalışmaların yeni bir mutfağı şekillendireceği düşünülse de, yaptıkları tartışmalar öylesine muhafazakârlık taşımaktaydı ki, antik çağın klasik zevklerinin canlanmasına çok az katkıda bulundu. Mutfaklardaki gözle görülür değişim aslında ilk modern yemek kitaplarının basılmasıyla başladı. 15. yy'da Como'lu Usta Martino'nun yazdı̆̆ 'Libro de arte coquinara (Aş̧̧ılık Sanatı Kitabı)' adlı kitap saray aşçıları için pratik bir kılavuzun ötesine geçememiş olsa da, kendisinden sonra yazılacak kitaplara öncülük etti. 'Platina' takma adını kullanan ve Papa IV. Sixtus'un Vatikan Kütüphanesi Müdürlügüne atadığı Bartolomeo Sacchi (1421-81), kaleme aldığ1 'De honesta voluptate et valetudine (Doğru Zevk ve İyi Sağllk Üzerine)' adlı kitabında hem antik çağ otoritelerinin (Apicius, Plinius Galenos vb.) sağlık ve yemek felsefesine hem de Martino'nun tariflerine yer verdi. İlk modern yemek kitabı olarak kabul edilen bu eser büyük bir ilgi gördü ve 19.yy'a kadar yaygın olarak kullanıldı. Platina'nın kitabını modern yapan şey ise sağlıklı beslenmeyi gastronomiyle yani zevk için yeme sanatıyla dengelemeye çalışmasıydı. Platina'nın kitabı bir yandan sağlıklı beslenmeyi gözetirken diğer yandan da ince bir gastronomi zevkini yüceltiyordu (Cowan, 2008:199).

1570 yılında Papa V. Pius'nin aşçısı Bartolomeo Scappi’nin 1570 yılında yayınladığı eseri ‘Opera dell'arte del cucinare'da 1.000'den fazla Rönesans yemeğinin tarifine yer verilmişti. Bu kitabın mutfak tarihi ve bu çalışma açısından önemi ise kitabın yemek yapım tekniklerine, mutfakta kullanılan araç-gereçlere ve mutfak tasarımına dair zengin görsellere sahip olmasıydı (örn. Resim 1). Alttaki örnekte verilen ana mutfak çizimi bu çalışmada ele alınan mutfak sahnelerine kılavuzluk etmektedir. Opera'da betimlenen ana mutfağa benzer bir şekilde, duvara bitişik bir ocak üzerinde zincirle asılmış kazanlar, ateşin üzerinde kızartılmak üzere şişe geçirilmiş etler, tavandan sallanan kancalara takılı taze etler veya balıklar, ortadaki ahşap çalışma tezgahları bu çalışmada ele alınan resim sanatı örneklerinde sıkça görülmektedir. 


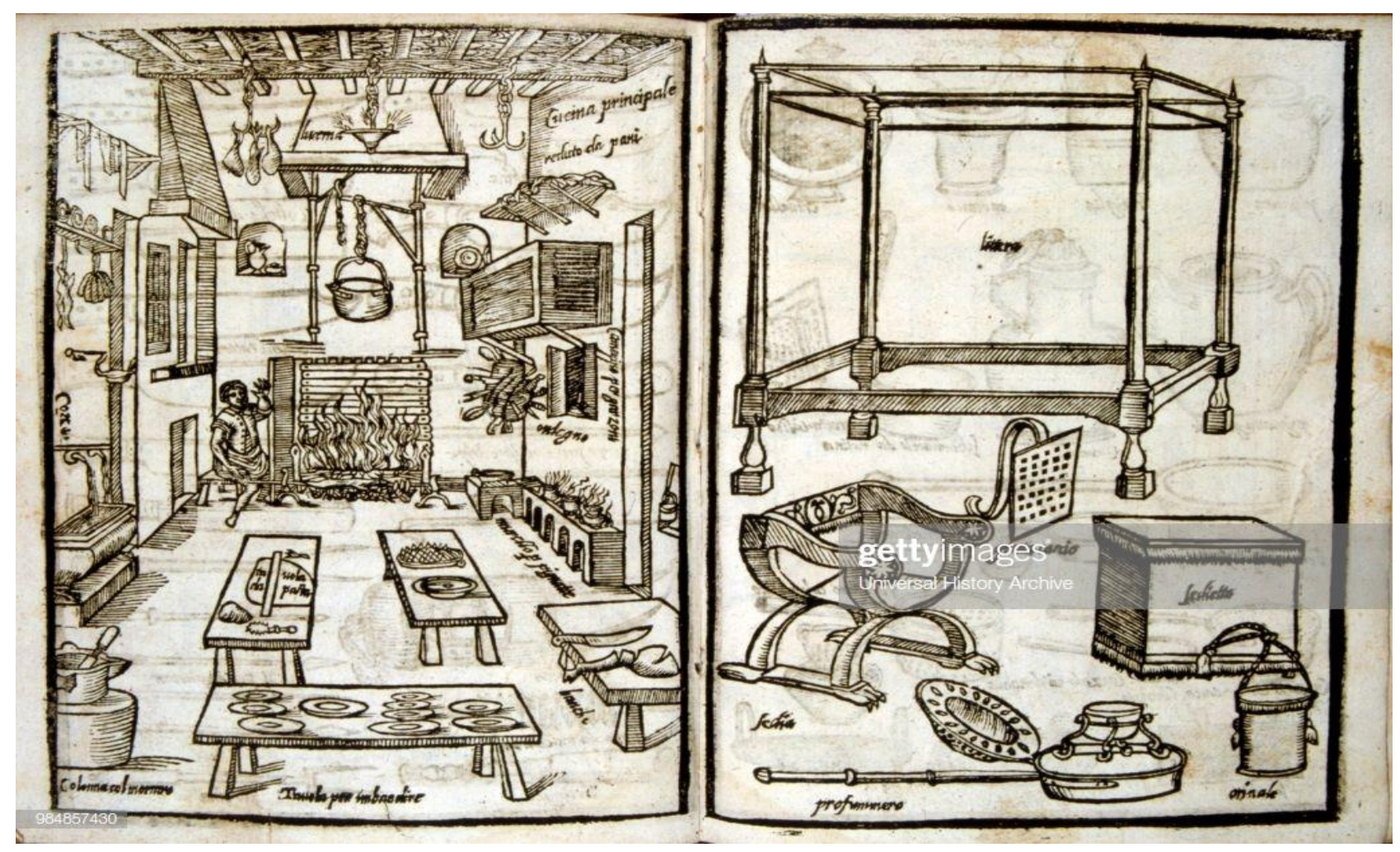

\section{Resim 1: Bartolomeo Scappi'nin 'Opera' adlı eserinden "ana mutfak” çizimi ve kullanılan bazı ekipmanlara dair çizimler, 1570}

Görüldüğü üzere Rönesans döneminde varlıklı sınıfların mutfakları genişledi. Merkezinde büyük bir şöminenin ya da birkaç küçük şöminenin olduğu geniş mutfaklar görülmeye başlandı. Şöminelerde, yakılacak oduna desteklik yapan demir ayaklıklar, 1zgara, kazanlar ve onları kaldırmaya yarayan zincir askılar bulunurdu. Yaklaşık olarak 17.yy ikinci yarısında döküm sobanın ve ocakların yaygın kullanılmaya başlanmasıyla tencere ve kazanlar bu ocaklar üzerine ve asılarak içine yerleştirilmeye başlandı. Kutlama yemeklerinde ve ziyafetlerde bu ekipmanlarla yapılan hazırlık davet sahibinin gösteriş yapmasına yardımcı oluyor, mutfaklara heyecan verici ve debdebeli bir görüntü veriyordu (Tez, 2012:108-115; Malaguzzi, 2012: 73). Bu dönemde mutfaklar, adeta bir simyacı laboratuvarı gibi davet sahibinin ve konukların gözlerinden uzaktı. Tam da bu dönemde resmi olan ile olmayan (gayrı resmi) ve kamusal olan ve olmayan (özel) alanlar arasındaki ayrım gittikçe keskinleşmekteydi. Ve usta aşçıların gastronomi harikaları, sosyal alanların arkasında, gözlerden uzak mutfaklarda şekilleniyordu. Dönemin gayrı resmi alanlarını ve gündelik hayat sahnelerini resmetmek isteyen bir sanatçı için mutfaklar oldukça elverişli mekanlardı. (Malaguzzi, 2012: 73).

Takip eden yıllarda Avrupa'da mutfakların yapısını etkileyen önemli olaylar gelişti. Keşfedilen yeni rotalar ve bu rotalarda kurulan köleci düzen Avrupa'nın yemek alışkanlıklarının değişmesinde neden oldu. Barok ve aydınlanma çağını yaşayan Avrupa'da, bir yandan yeni icatlar yapılıyor bir yandan da yenidünyaların yeni gıdaları olan çikolata, kahve, çay ve şeker ile tanışıyordu. Özellikle kolonilerde kurulan şeker plantasyonları sayesinde şekerin üretim kapasitesi ve Avrupa' da 'tatlı' olarak kabul edilen yemeklerde şeker kullanımı arttı. Şekerin Avrupa'da gördüğü büyük rağbetle birlikte şekerlemeye dayanan yeni bir mutfak ve yemek sanatı doğdu (Cowan, 2008).

Avrupa elit mutfağına ve mutfak tasarımına yön veren bir başka devrim ise XIV. Louis döneminde gerçekleşti. Bu devrimin ilk belirtisi 'La Varenne' takma adıyla bilinen François Pierre (yakl. 1618-78)'in Le Cuisinier François adlı kitabını 1651 yılında yayınlamasıyla baş gösterdi. Platina'nın kitabının ve onu izleyen pek çok eserin aksine La Varenne'in kitabı, beslenme yoluyla sağlığı iyileştirme amacı gütmüyordu. Bu eser çok ayrıntılı olarak yemek hazırlama ve pişirmeye öncelik veriyor, mutfağın sağlık ve tıp alanı ile ilişkisinden kopuyor ve modern Avrupa gastronomisinin yolunu açıyordu. Kitapta tarif edilen soslar, tereyağ ve kremanın yoğun kullanımı Fransız mutfağının yeniden şekillendiriyordu. Kitapta Fransızca orijinalleriyle kullanılan ifadeler standart aşçlık terimleri haline geliyor ve bu yeni gastronomi dili nüktedan edebi çevrelerde yeni elit aşçı1ık tarzını oldukça süslü ve kibirli gösteriyordu (örn. Resim 12) (Cowan, 2008). 
Gittikçe zenginleşen burjuva sınıfının sahip olduğu bolluğu resmetmek için mutfaklar ve yemek hazırlığı yapılan yerler ressamlara büyük firsatlar sunuyordu. Eserin siparişini veren sanat patronlarını memnun etmek isteyen ressamlar zenginliğin ve bolluğun dolup taştığı mutfakları yansıtabilmek için pek çok yöntem kullandılar. Bu sayede yemek alanından ayrılmış geniş ve aydınlık mutfaklar 18. ve 19. yy'da görülmeye başlandı. İri yarı, kaslı kollu, al yanaklı, yorgun ama gururlu mutfak çalışanlarının yerini daha ince yapılı figürler aldı. Aşçıbaşılarının yaptığı işler takdir gören bir meslek olarak öne çıktı. Mutfaklar daha düzenli hale geldi. Ekipmanlar çalışanların daha kolay ulaşabileceği raflara dizilmeye ve asılmaya başlandı. Bu sayede güç gerektiren ağır işler azaldı. Ateş artık daha da kolay kontrol edilebiliyordu. Şöminelerde görülen açık ateş bir kuzinenin içine hapsedildi ve mutfak kaplarının ve kişilerin doğrudan ateş ile teması azaldı. Bu da mutfakta daha az yorulan hatta güzel vakit geçiren figürleri mutfakta görmemizi sağladı. Önceki döneme ait resimlerde adeta güreşircesine hummalı bir şekilde çalışan mutfak çalışanlarının yerini birasını yudumlayan, dikiş diken, gülümseyen kadın figürler ve oyun oynayan çocuklar aldı.

\section{RESIM SANATINDA MUTFAKLAR}

Yiyecek ve içeceklerin yer aldığ 1 görsel eserler çok eskilere tarihlenir. Av olma korkusunu mağara duvarlara yansıtan Taş Çağı insanı belki de ilk yiyecek resmini yaratmıştır. Tabi burada yiyen ve yenilen (avlayan ve avlanan) tarafların sürekli değiştiğini belirtmekte fayda var. Yerleşik yaşama geçişle birlikte tarım faaliyetlerine ağırlık veren ilk medeniyetler, tükettikleri veya kendileri için sembolik anlama sahip olan yiyecek ve içecekleri resmetmeye devam etmişlerdir. Çatalhöyük'teki kazılarda evlerin duvarlarında bulunan ayrıntılı avlanma sahneleri, Antik Mısırlıların piramitlerin iç duvarlarında şarap ve ekmek yapımını gösteren resimli betimlemeler, Antik Yunan'da yer mozaiklerinde, mermer kabartmalarda, heykellerde gördügümü̈z yiyecek öğeleri, Pompeii ve Herculaneum'da bulunan duvar natürmortları bu yiyecek-içecek öğelerine ait resim örnekleridir. Bunlar bazen din adına yapılmış bazen de din dışı bağlamda ele alınmışlardır. Hıristiyanlıktan beslenen Ortaçağ resim sanatında yiyecek-içecek öğelerini ancak kutsal mesellerde geçiyorsa görebiliriz. Örneğin Hz. İsa'nın suyu şaraba dönüştürmesi, beş ekmek ve iki balık mucizesi gibi kutsal sahneler betimlenirken bu yiyecek öğeleri resmedilmiştir. Özellikle Son Akşam Yemeği, Emmaus'da Yemek, Belşazzar'ın Şöleni gibi kutsal kitap metinleri betimlenirken yemek masaları da resmedilmeye başlanmıştır. Kutsal kitapta geçen "İsa'nın Martha ve Meryem'in Evinde" öyküsü ise yiyeceklerle birlikte bir mutfağın da resmedilmesini sağlamışır. 15.yy'da başlayan Rönesans ve beraberinde gelen Hümanizm akımıyla birlikte ilgi alanını doğa ve insan olarak değiştiren sanat dünyası, yüzünü Antik dönemin mitolojik konularına dönmüş ve mitlerde geçen yiyeceklere, şölenlere ve zengin sofralara resimlerinde yer vermeye başlamıştır. Özellikle 16.yy'ın sonlarından itibaren ölüdoğa resimlerinde görülmeye başlanan yiyecek-içecek öğeleri, Hollanda sanatının konusunu günlük yaşamdan alan resimlerinde daha yaygın bir şekilde yer almaya başlamıştır. "Janr", "tür" ya da "genre" olarak da adlandırılan bu sanatta sıradan insanların günlük yaşamları, öğünleri, yemek hazırlıkları, mutfaklar, sofra eğlenceleri ve sofra gelenekleri gibi sıradan konular sıklıkla yer bulmuştur (Akdeniz, 2017; Farthing, 2014; Grombich, 2013; İren Boynudelik ve Önel Kurt; 2018:59).

\section{RESIM SANATINDA YEMEK HAZIRLIKLARI VE MUTFAK SAHNELERINNDEN ÖRNEKLER}

Aristokratik mutfakların genellikle erkekler tarafından yönetildiği 16.yy'ın sonlarına doğru, Hollanda resim sanatında güçlü ve heybetli kadınlar mutfak sahnelerinde sıklıkla karşımıza çıkarlar. Pieter Aertsen tarafından ele alınan "Aşçı" (Resim 2) isimli tabloda açık alanda çıplak bir ateş yerine bir Yüksek Rönesans mimarisini yansıtan bir şömine görürüz. Şöminenin klasik yapısına bakılırsa burası varlıklı bir ailenin mutfağıdır ve şöminenin önünde poz veren kadın da evin aşçısıdır. Bu kadın elinde demirden yapılma ağır bir şişe bütün kümes hayvanlarını ve büyük bir parça kuzu bacağını dizer. Figürün duruşuna ve kaslı kollarına bakılırsa, taşıdığı şişin ağırlığı onun için hiçbir sorun teşkil etmemektedir. Onun gururlu duruşunda Ortaçağ' in itaatkar ve teslimiyetçi kadın profilinden eser yoktur. Böylesine anıtsal duruşuyla o bir aşçıdan çok klasik dönemlerin bereket tanrıçasına benzetilir (Bendiner, 2004:77; Riley, 2015:272; Sullivan, 1999:236). 


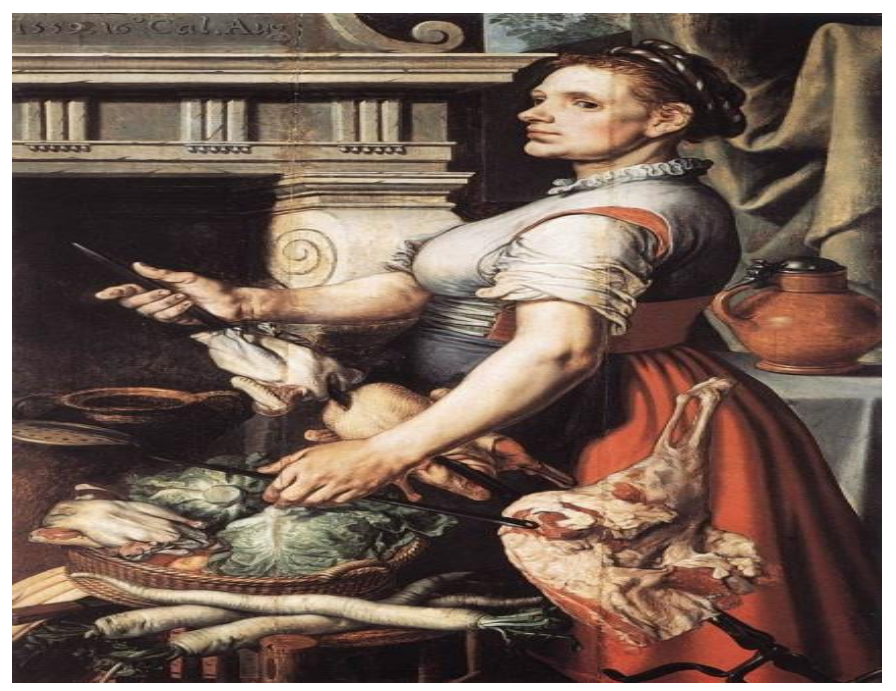

Resim 2: Pieter Aertsen, Așçı (The Cook), 1559, Musées Royaux des Beaux-Arts, Brüksel.

Joachim Beuckelaer'in Dört Unsur tablosunun son tablosu olan “Ateş”te (Resim 3) dikkatimizi çeken ilk unsur mutfağın arka planda gösterilen yaşam alanından ayrılmış bir mekan olmasıdır. Bu resimde ön plandaki geniş mutfakta ağır ve kol gücü gerektiren işlerle uğraşan iki kadın figür bulunur. Bu dönemde günümüzün mutfaklarına girmeyen bazı işlerin (örn. bir kümes hayvanının tüylerinin yolunması, başın gövdeden ayrılması, iç organların çıkarılması vb.) henüz mutfağın içinde yapıldığı görülmektedir. Bu sahne, arka plandaki ateşte pişirilmek üzere hazırlanan etlerin ve kümes hayvanlarının adeta natürmortudur. $\mathrm{Bu}$ dünyevi sahnenin arkasında merkezde ocağın yanında hummalı bir tüketim içinde iki kadın ve bir erkek figür bulunur. Yere saçılmış boş kaplar, tabaklar ve midye kabukları aşırı tüketim ve savurganlığın temsilidir. Sahnenin en gerisinde sol arka köşede ise 'Martha ve Meryem'nin Evindeki İsa' betimlenmiştir. Kutsal sahne, Hz. İsa'nın Kudüs'e yolculuğu sırasında durakladığı iki kız kardeşin evindeki yemeği konu alır. İsa'yı ağırlamak için yoğun bir hazırlığa kendini kaptıran Martha'nın aksine Meryem, İsa ile sohbet etmeyi, onun öğretilerini dinlemeyi tercih eder. Martha bu meselde faal hayatı temsil ederken, Meryem de en doğru ve en güvenilir olan tefekkür hayatı temsil etmektedir. Ön planda Martha ve diğerlerinin yemek hazırlığını konu alan din dışı sahneden kapının arkasındaki dinsel sahneye doğru uzanan bu tabloda yine geçici zevklerden ve dünyevi işlerden Tanrı'ya ve onun öğretilerine doğru yönelim vurgulanmıştır (Akdeniz, 2017:94; Irmscher, 1986; Riley, 2015:274). 


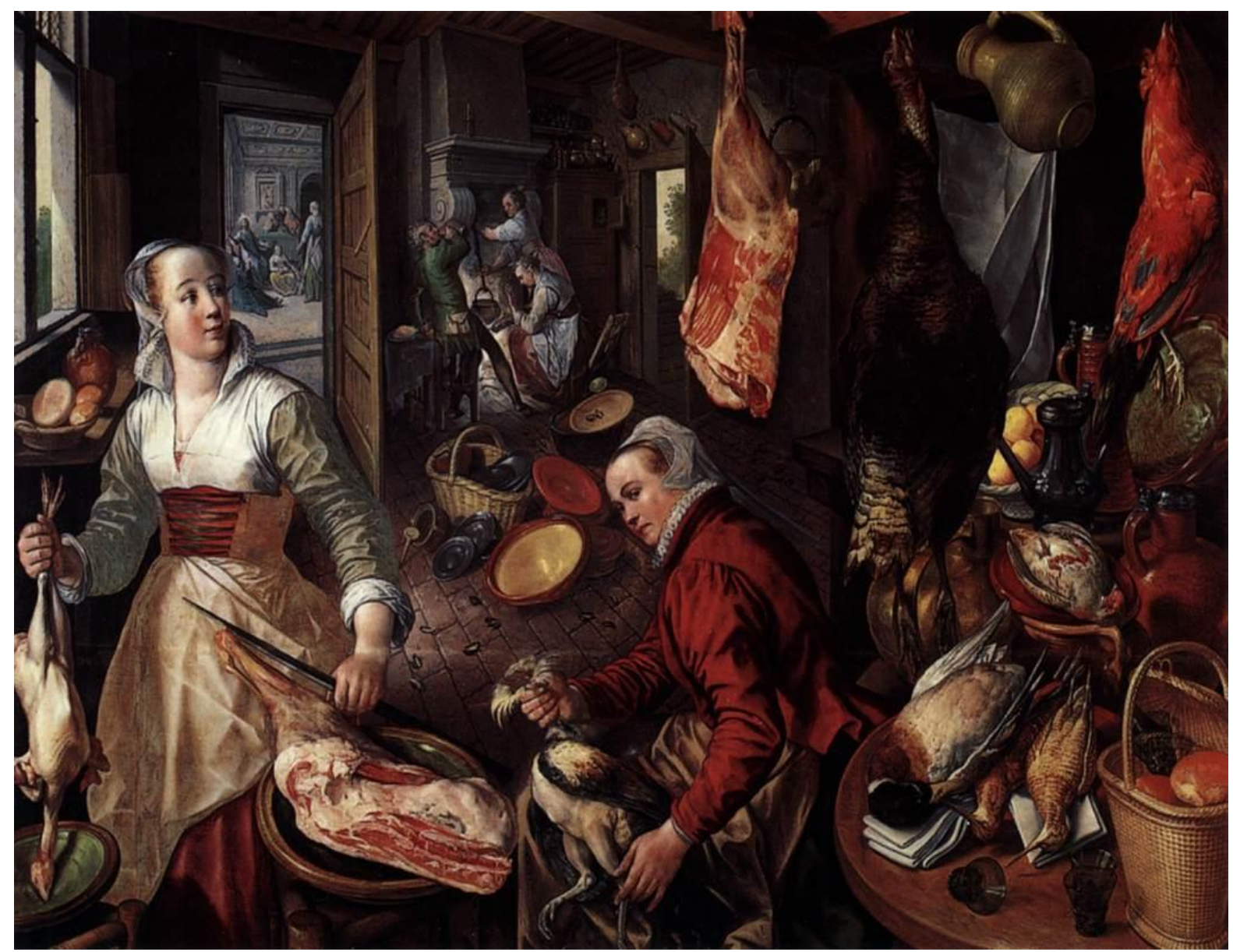

Resim 3: Joachim Bueckelaer, Dört Unsur: Ateș (The Four Elements: Fire), 1570, National Gallerv. Londra.

Bir mutfak içinde tasvir edilen resimlerin en önde gelenlerinden birkaçı şüphesiz ki Bassano ailesinin üyelerine aittir. Bassano ailesinin ressamları (Jacopo, Leandro ve Francesco) öncülleri ve çağdaşlarından farklı olarak mutfak sahnelerini oldukça ayrıntılı ele almıştır. Örneğin İtalyan resim sanatının büyük ustası Paolo Veronese, çok büyük ebatlarda şölen sahneleri ortaya koymuş olsa da, yemeğin yapımını ve sunumunu Bassano'larınkiler kadar detaylandırmamıştır. Ya da Papa Pius V'nin aşçıbaşısı Bartolomeo Scappi'nin 1570 yılında yayınladığı "Opera" adlı kitabındaki kılı kırk yaran binlerce yemek reçetesinde bile böylesine detaylar görülmez. Bu nedenle Bassano'ların mutfak üzerine verdiği ayrıntılar mutfak tarihi açısından çok önemlidir (Gürsoy, 2014:155; Riley, 2015: 295)

Kleopatra ve Antonius'un ziyafetini konu alan alttaki eserinde (Resim 4) Leandro Bassano, Scappi'nin gösterişli ve yüksek menülerinin hazırlanmasına ait detayları oldukça net ortaya koymuştur (Riley, 2015:296). Tablonun daha iyi anlaşılabilmesi için arka planda betimlenen efsaneye kısaca yer vermekte fayda var. Marcus Antonius, Mısır Kraliçesi Kleopatra onuruna eşi benzeri olmayan lüks içinde bir ziyafet vermiştir. En pahalı yemeklerin ardı arkası kesilmez. Ancak kraliçe bundan hiç etkilenmez. Gururlu davet sahibine, kendisinin o ana değin sunulan tüm yemeklerden çok daha pahalısını hazırlayabileceğini söyler. Sonra inci küpelerinden birini çıkarıp sirkenin içinde eritir ve bu karışımı içer (Akdeniz, 2017:225). İncinin de maliyet olarak hesaplanmasıyla birlikte Kleopatra'nın bu davet için çok daha bonkör olduğu ispatlanmış olur. Tarihin şüphesiz ki en çekişmeli yemek yarışlarından biri olan bu sahne Bassano'nun tablosunun arka planındaki masada gösterilmiştir. Kleoparta sağ elinin parmaklarıyla küpesini çıkartırken görülür.

Ön planda görülen mutfak düzenine baktığımızda dönemiyle paralellik gösteren bir mutfak tasarımı görürüz. Burada şömine ressamın kadrajına girmemiştir. Ama şöminede pişirilecek kanatlıları şişe dizen kadına bakılırsa şömine çok yakınlarda bir yerde olmalıdır. Tabakların dizildiği üst raf izleyicinin dikkatini kolaylıkla çeker. Öndekilerin kenarlarında sırmalar çekilmiş çok sayıda ve farklı büyüklerde metal tabaklar raflara muntazam dizilmiştir. Leandro Bassano'nun tablosunda ön planda oturan ve elinde bıçakla küçük bir 
kanatlıyı keserken görülen baş aşçı kafasındaki kırmızı başlığıyla kendisini kolayca ayırt etmemizi sağlar. Aşçıaşının baktığı yönde satenden yapılma ve sırtı yırtmaçlı kıyafetleriyle gösterişli bir uşak bulunur. Uşak elindeki işlemeli büyük servis tabağını aşçıbaşına doğru uzatarak servise uygunluğunu sormaktadır. Kırmızı püsküllü başlığı ve gösterişli kıyafetleriyle ayakta duran bir diğer garson ise masadaki yemek yığınına yeni bir tabak eklemek üzere görülmektedir (Riley, 2015: 296-97). Aşçıbaşının yanındaki alçak masada ise en son servis edilecek tatlılar ve şekerlemeler bulunmaktadır.

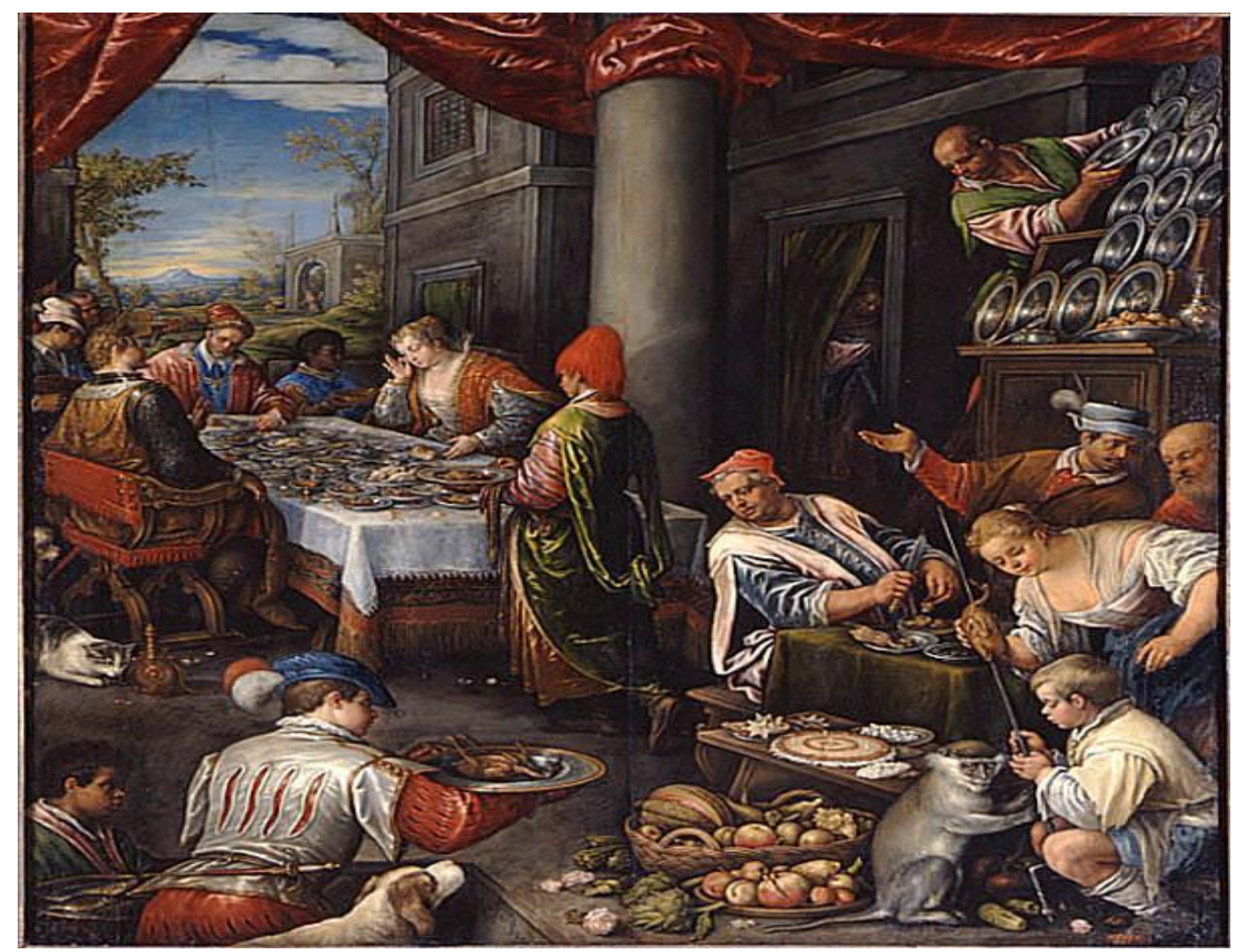

Resim 4: Leandro Bassano, Kleopatra ve Antonius’un Şöleni, yakl. 1610

Jacopo Bassano’nun "Martha ve Meryem'nin Evindeki İsa” adlı tablosunda (Resim 5) bir öncekine oldukça benzeyen bir mutfak görülmektedir. Daha önce Beuckelear'ın "Ateş" tablosunda ve mutfak temalı pek çok resimde işlenen bu kutsal meselin Jacopo Bassano tasvirinde İsa bir evin mutfağına giriş yaparken gösterilmiştir. Sol tarafta bir kemerden mutfağa giren İsa'nın sağında diz çökmüş Meryem, önünde ise onu içeriye buyur eden Martha bulunmaktadır. Bundan önce değindiğimiz Leandro Bassano tablosunda da gördüğümüz kırmızı başlıklı aşçı bir yandan elinde bıçağıyla salam dilimlemekte diğer yandan da solunda şömine ateşiyle ilgilenen kadın figürün ne yaptı̆̆ına bakmaktadır. Aşçının çalıştığı masanın üzerinde İsa'nın kanını sembolize eden şarap ve üzüm ile bedenini sembolize eden ekmek (Resim 5b) bulunmaktadır. Aşçının arkasında gümüş servis tabakların dizildiği duvara asılı bir raf görülür. Aynı rafa iliştirilmiş çengellere bakır tencereler ve tüyleri yolunmuş kümes ya da av kuşları baş aşağı asılmıştır (Resim 5a). 


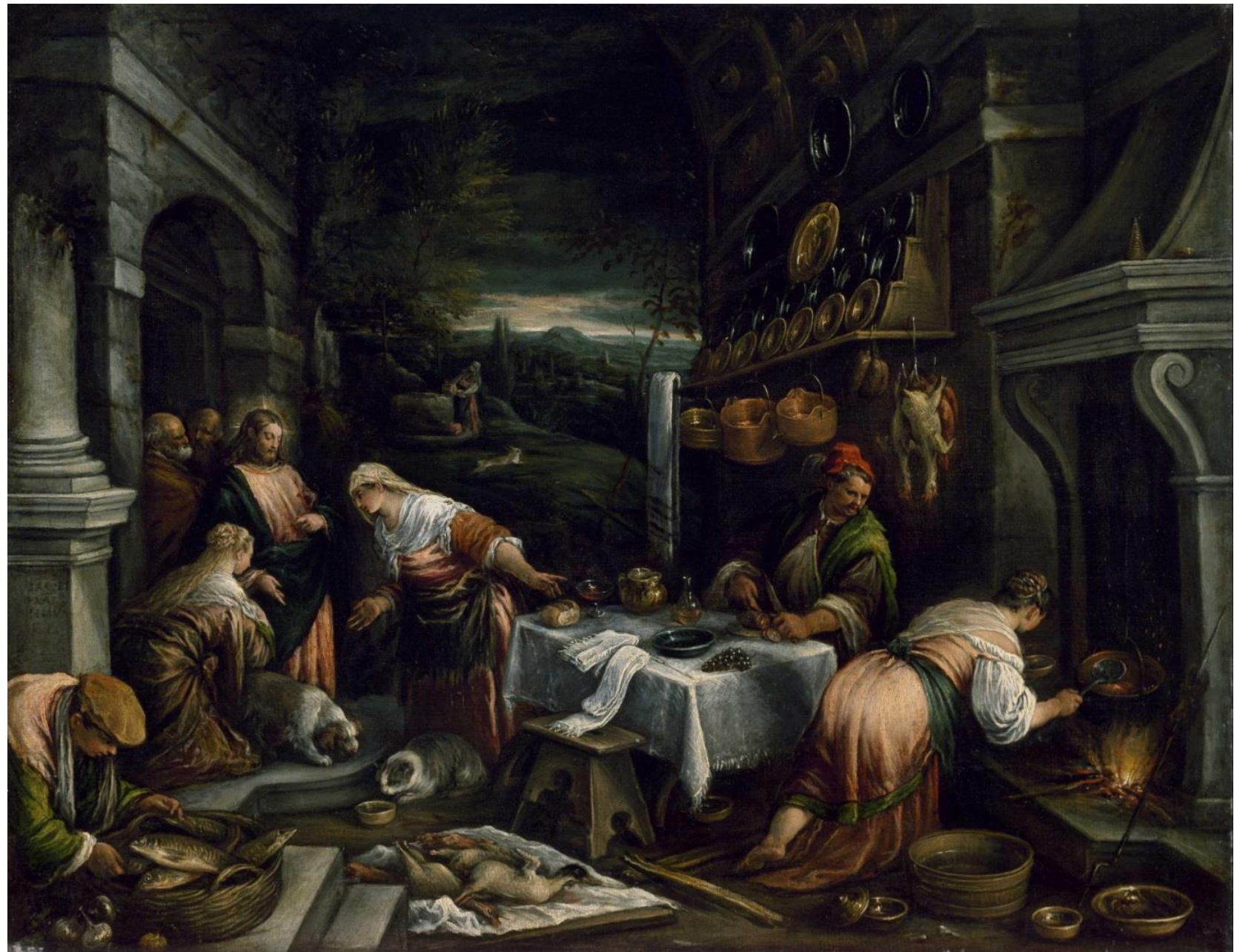

Resim 5: Jacopo Bassano, Martha ve Meryem'nin Evindeki İsa (Christ in the House of Martha and Mary), yakl. 1576-77, Museum of Fine Arts, Houston
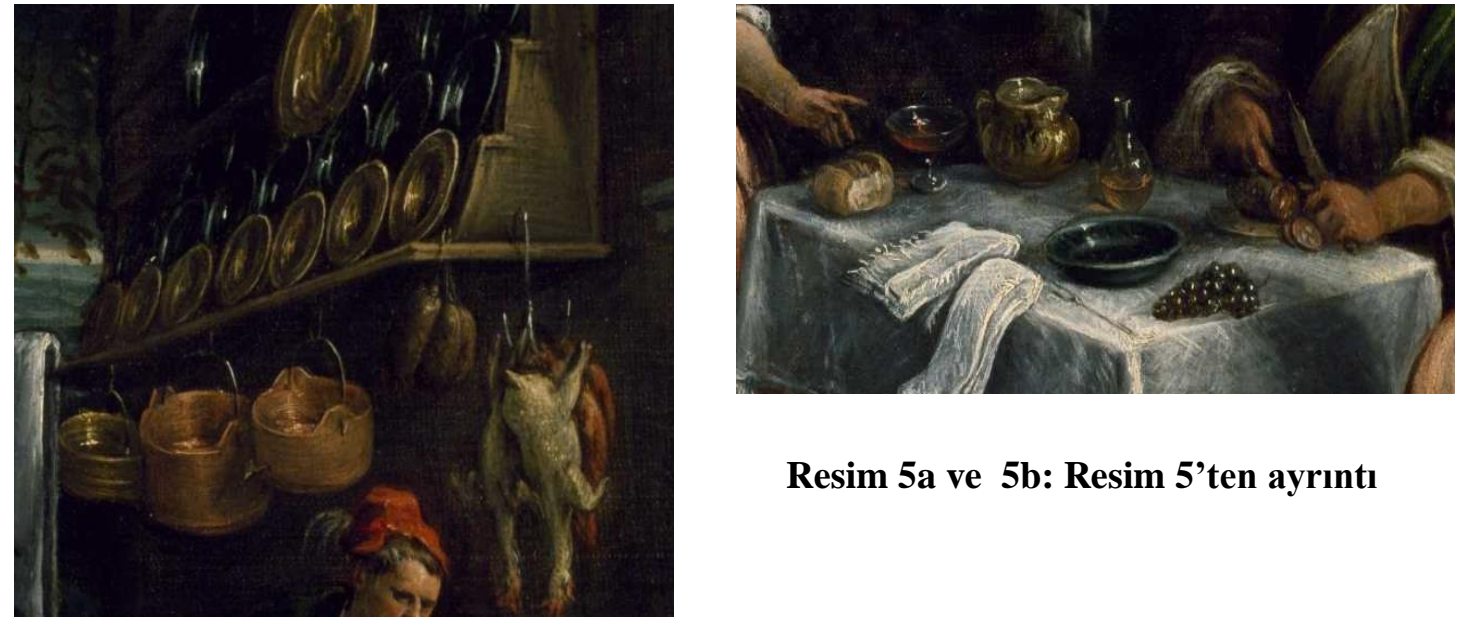

\section{Resim 5a ve 5b: Resim 5'ten ayruntı}

Hummalı yemek hazırlıklarının resmedildiği bir diğer eser ise Hollandalı ressam Joachim Wtewael'e aittir. Wtewael'in "Mutfak Sahnesi" (Resim 6) eserinde ön planda kargaşanın hakim olduğu bir mutfak ve arka sağ planda ise özel bir yeme alanında İncil'de bahsi geçen "Şölen Benzetmesi (The Parable of the Great Banquet - Luka, 14: 12-24)" tasvir edilir. Oldukça küçük bir kareyle resme dâhil edilen bu mesele göre, İsa davetli olduğu bir yemekte, büyük bir ziyafet hazırlatıp birçok konuk çağıran bir adamın öyküsünü anlatır. Öyküdeki adam ziyafet saati geldiğinde, davetlilere her şeyin hazır olduğunu söylemesi için hizmetkârını gönderir. Ancak davetlilerin çeşitli mazeretlerle gelmeyeceğini öğrenip öfkelen davet sahibi, bu kez hizmetkârından 
sokaklardaki tüm yoksul ve kötürümleri çağırmasını ve daha önce davet edilip de gelmeyen hiçbir kişinin onun yemeğini asla yeme şansına sahip olmayacağını söyler (Bendiner, 2004:79; İren Boynudelik ve Önel Kurt, 2018:60; Malaguzzi, 2008: 158).

Wtewael'in "Mutfak Sahnesi"nde (Resim 6) İsa'nın anlattığı öyküde yer alan adamın verdiği davetin hazırlıkları görülür. Ön plandaki karmaşanın hâkim olduğu bu sahneler dikkatle incelendiğinde hazırlığın soldan sağa doğru bir sıra takip ettiği görülür. En solda iç organları ayırma, tüylerin yolunması, temizleme, parçalara ayırma gibi kaba ve zalim işlemleri uygulayan erkek bir figür bulunur. Burada yığınlar halinde yerlerde duran balıklar doğrudan kurtarıcı İsa'ya gönderme yapmaktadır. Raflara bacaklarından baş aşağı asılmış diğer av hayvanları da aristokratik ve varlıklı bir ortamı ve davet sahibine işaret eder. Ortadaki kadın figür ise yarı hazır hale getirilmiş parçaları bir şişe geçirir. Ziyafetlere teatral bir hava ve gösteriş kattığ için yiyeceklerin şişe geçirilmesi, resmin yapıldığı dönemlere ait zengin ziyafetlerin oldukça sık başvurduğu bir pişirme yöntemiydi. Şu ana kadar gördüğümüz tüm kadın figürlerde olduğu gibi burada da yapılı ve güçlü bir duruş göze çarpar. Mutfakta her türlü işi görebilen güçlü ve erkeksi kadınlardır bunlar. Daha arka planda başka bir kadın figür ise havanda bir şeyler öğütmektedir. Öğüttüğü şey muhtemelen zenginleşen Flaman ülkelerinde görülen baharatlardır. Resmin sağ planında ise büyük bir ateşin başında iki figür görülmektedir. Bunlar sanki kaçamak bir ilişkinin içinde gibi görünürler. Elindeki sepetten evin yiyecek tedarikçilerinden biri olduğu anlaşılan erkek figür, bir yandan sağ elinde şarap kadehi tutmakta, diğer yandan da kadın figüre daha çok yaklaşmaya çalışmaktadır (İren Boynudelik ve Önel Kurt, 2018:60-61; Malaguzzi, 2008:158).

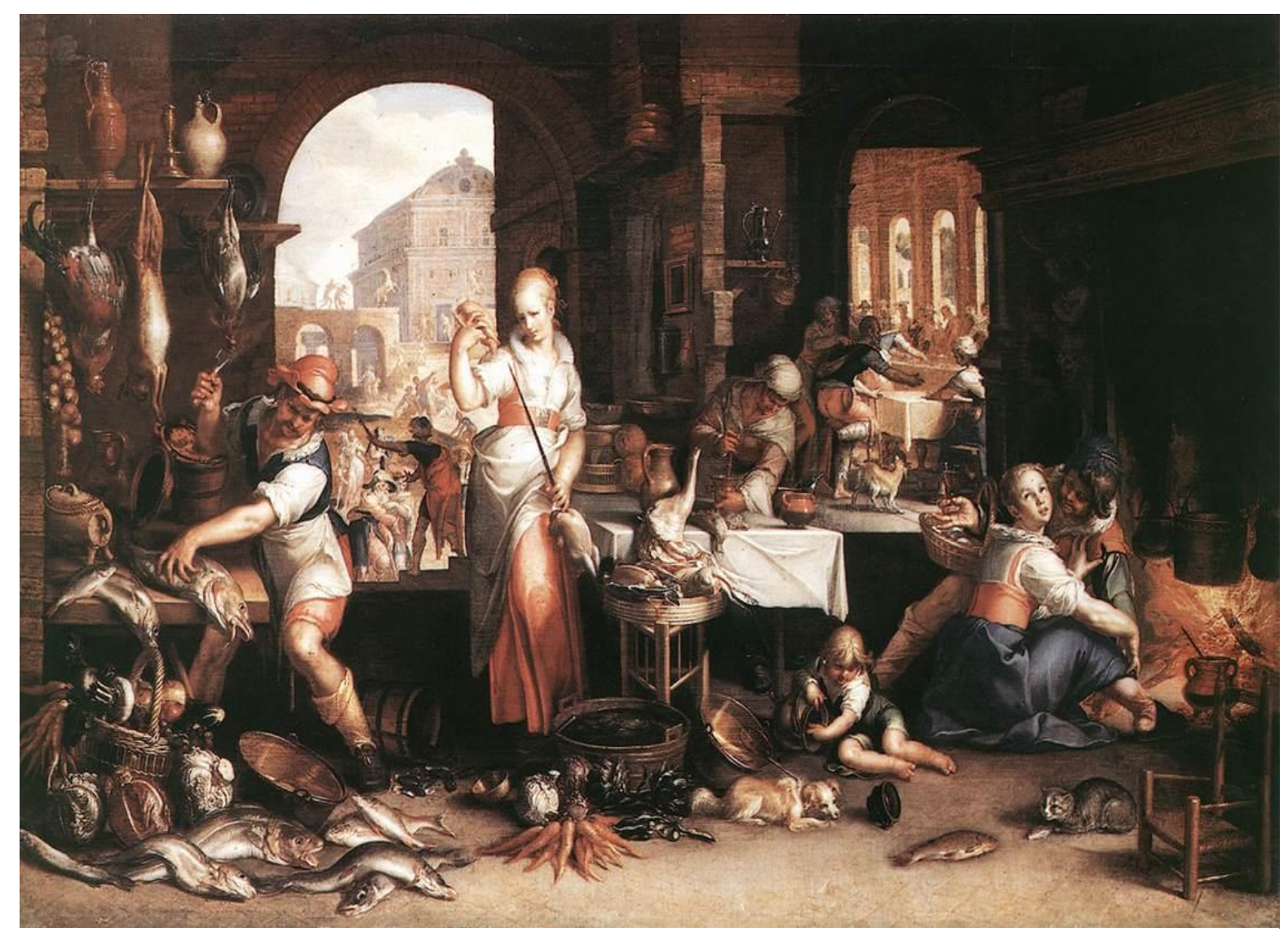

Resim 6: Joachim Anthonisz Wtewael, Mutfak Sahnesi, 1605, Staatliche Museen, Berlin

Benzer bir mutfak yapıs1, Vincenzo Campi'nin "Mutfak Sahnesi" (Resim 7) adlı resminde bir evin mutfağında kendisini bir davet yemeğinin hazırlığına kaptırmış geniş bir ailenin üyeleri betimlenmiştir. Diğer örneklerde gördüğümüz gibi burada da bir şömine, faklı boyutlarda pek çok tabağın dizildiği büyük bir raf ve arka planda mutfaktan ayrı bir yemek alanı bulunmaktadır. Ortadaki tezgâhın üzerinde görülen yumurta, tereyağı, un ve hamur açmakla ilgilenen kadınlar sayesinde otlu turta (torta d'herbe) hazırlandığını anlayabiliyoruz (Resim 7a). Onların sağında arkası dönük kadın figür elindeki bıçak yardımıyla yarım daire şeklinde kapatılmış turtanın kenarlarını süslemektedir (Resim 7b). Resmin merkezinde doğrudan izleyiciye bakan kadın figür büyük bir peynir parçasını rendelerken görülür. Onun yanında oturan yaşlı kadın havanda 
dövdüğü otların tadına bakmaktadır. Öndeki iri yarı kadın figür av kuşlarını pişirmek üzere ayıklarken onun arkasındaki genç oğlan sert bir ifade ile ayıklanmış hayvanları şişe geçirir.

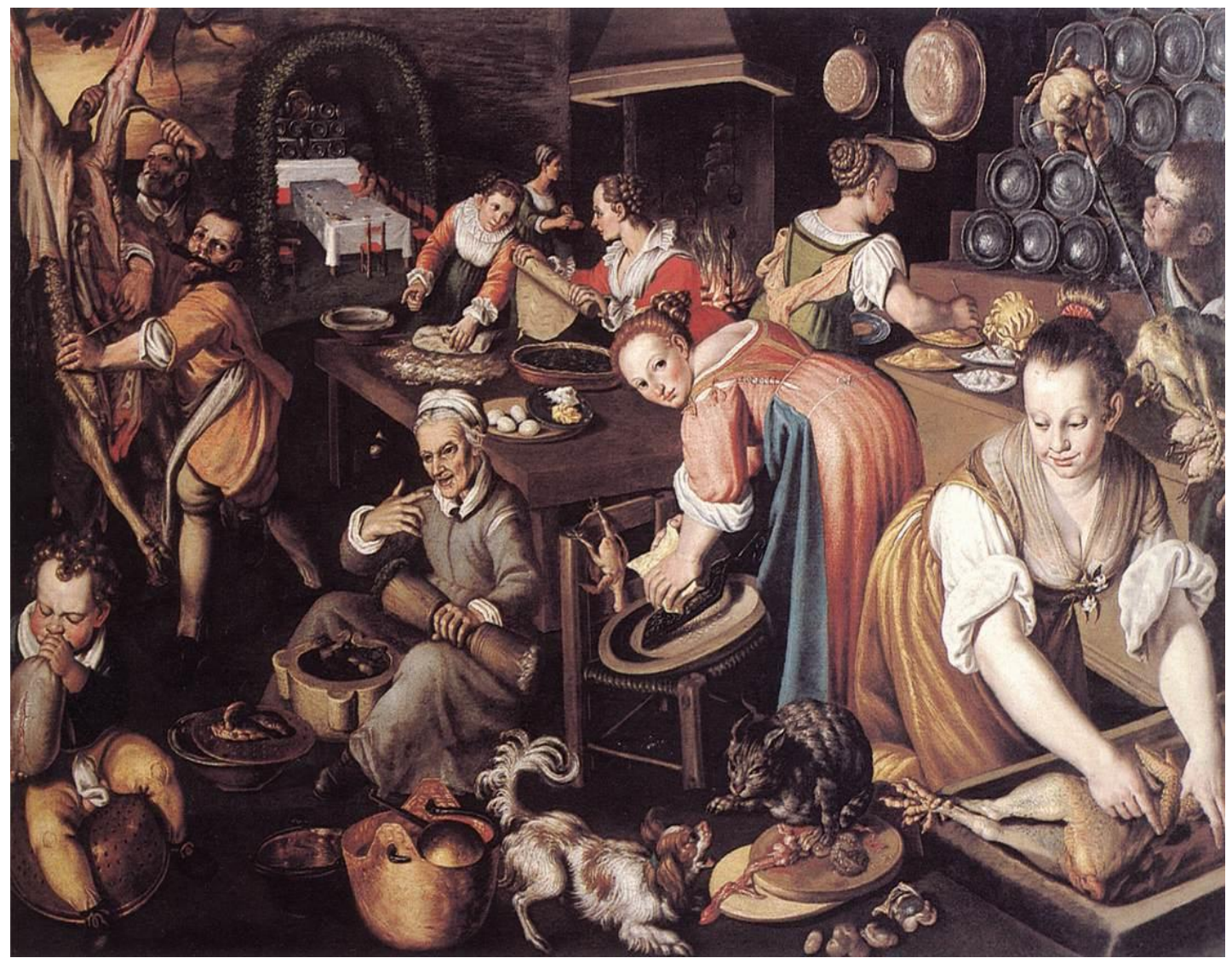

Resim 7: Vincenzo Campi, Mutfak, 1590-91, Pinacoteca di Brera, Milano

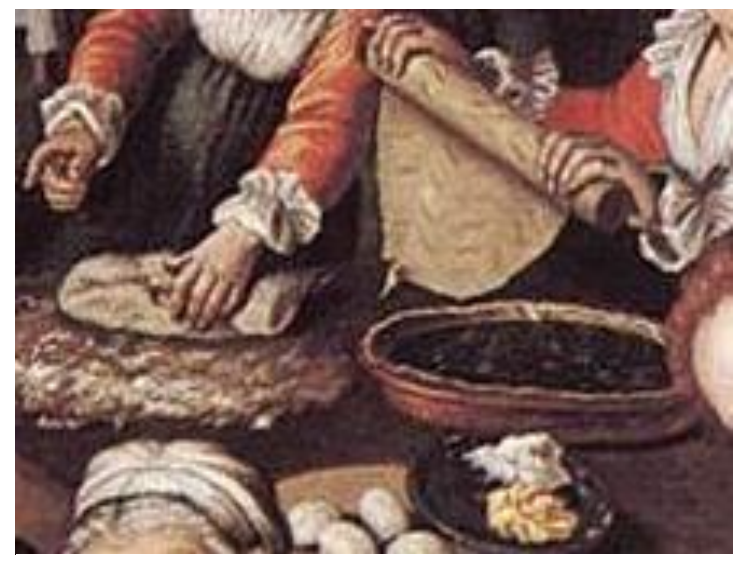

Resim 7a: Resim 7'den ayrıntı

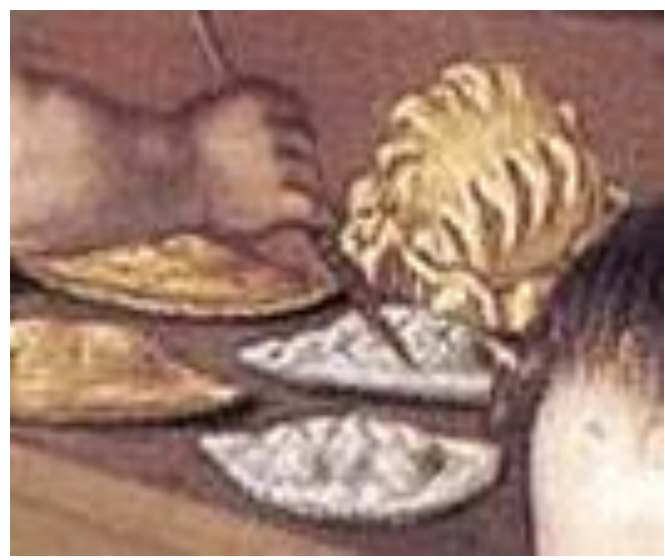

Resim 7b: Resim 7'den ayrıntı

Campi'nin resminde de Wtawael'in “Mutfak Sahnesi”nde olduğu gibi yemek hazırlıklarında soldan sağa bir sıralama söz konusudur. Sol üst köşede iki adam bir karkası parçalar. Ön planda hayvanın içinden çıkan işkembeyi üfleyen bir çocuk bulunur. İzleyiciye oldukça ilginç gelebilecek nitelikteki bu görüntü resim sanatında insanın hayatının metaforik bir ifadesi olarak yer bulur. Şöyle ki: M.Ö. 116 - M.Ö. 27 yılları arasında yaşamış olan Romalı akademisyen ve yazar Marcus Terentius Varro, insan yaşamını bir sabun köpügüne benzetmiştir. Latincede 'Homo Bulla' olarak kalıplaşmış bu ifadede, sadece çok kısa bir an için gökkuşağının parlak renkleri ile 1şıldayan ama en küçük bir esintide patlayıp yok olan sabun köpüğü ile insan hayatı arasında metaforik bir ilişki kurulmuştur. Homo bulla bu yönüyle, insan yaşamının tıpk1 sabun köpüğü gibi gelip geçiciliğini ve maddi dünyaya ait parıltılı zevklerin bir gün son bulacağını ifade eden bir imgedir. Hollanda resim sanatında ve 'vanitas' resim türünde kutsallık ve manevi dünya karşıtlığını vermek için özellikle çocuklar tarafından şişirilen bir öğe (bazen işkembe bazen de sabun) olarak karşımıza çıkar. 
Oldukça iri ve sıhhatli görünen kadın figürlerin sayıca baskın olduğu bu mutfak sahnesinin geri planında bir figürün hazırladığı bir yemek masası bulunur. Bu ailede herkes çalışmakta ve hane halkı üretimine katkıda bulunmaktadir.

$\mathrm{Bu}$ eserin resmedildiği tarihlerde mutfak sahnelerinin betimlendiği bu tür resimler adeta bir yemek kitab1 işlevi görüyordu. Çünkü halk gıdaların nasıl hazırlanıp pişirilmesi gerektiği konusunda pek fazla bilgiye sahip değildi. Bu da ekonomi için büyük bir israf demekti ve ciddi bir sorun teşkil ediyordu. Bu tür resimler tam bu noktada devreye giriyor ve yemek yapımına dair sundukları görsel bilgi aracılığıyla bu önemli ekonomik sorunun giderilmesinde rol oynuyordu. Pek çok mutfak ekipmanının işlevinin kolayca anlaşılmasını sağlayan böylesine hareketli sahneler, mutfaktaki süreçler ve roller hakkında çok daha açıklayıcı bir işlev görüyor ve bahsedilen ekonomik sorunun giderilmesinde önemli rol oynuyordu. Daha önce bahsedilen Papa Pius V'nin aşçısı Bartolomeo Scappi'nin 1570 yılında yayınlanan eseri Opera'da mutfaklar, ekipmanlar ve yapılan işler üzerine pek çok çizim bulunuyordu (Örn. Resim 1). Ancak bu çizimler oldukça statikti ve tasvir edilen unsurların ne işe yaradığını ve hangi amaçla kullanıldığını anlayabilmek için derinlemesine düşünmek ve zihinde kurgulamak gerekiyordu. Ancak resim sanatında mutfak öğeleri figürler tarafından kullanılırken betimlenmiş ve ne amaçla kullanıldığı çok daha kolay anlaşılmaya başlanmıştı (Akdeniz, 2017: 60; Riley, 2015:279).

Mutfakların tarihinden bahsederken 16.yy’dan sonra keskinleşen resmi olan ile olmayan (gayrı resmi) ve

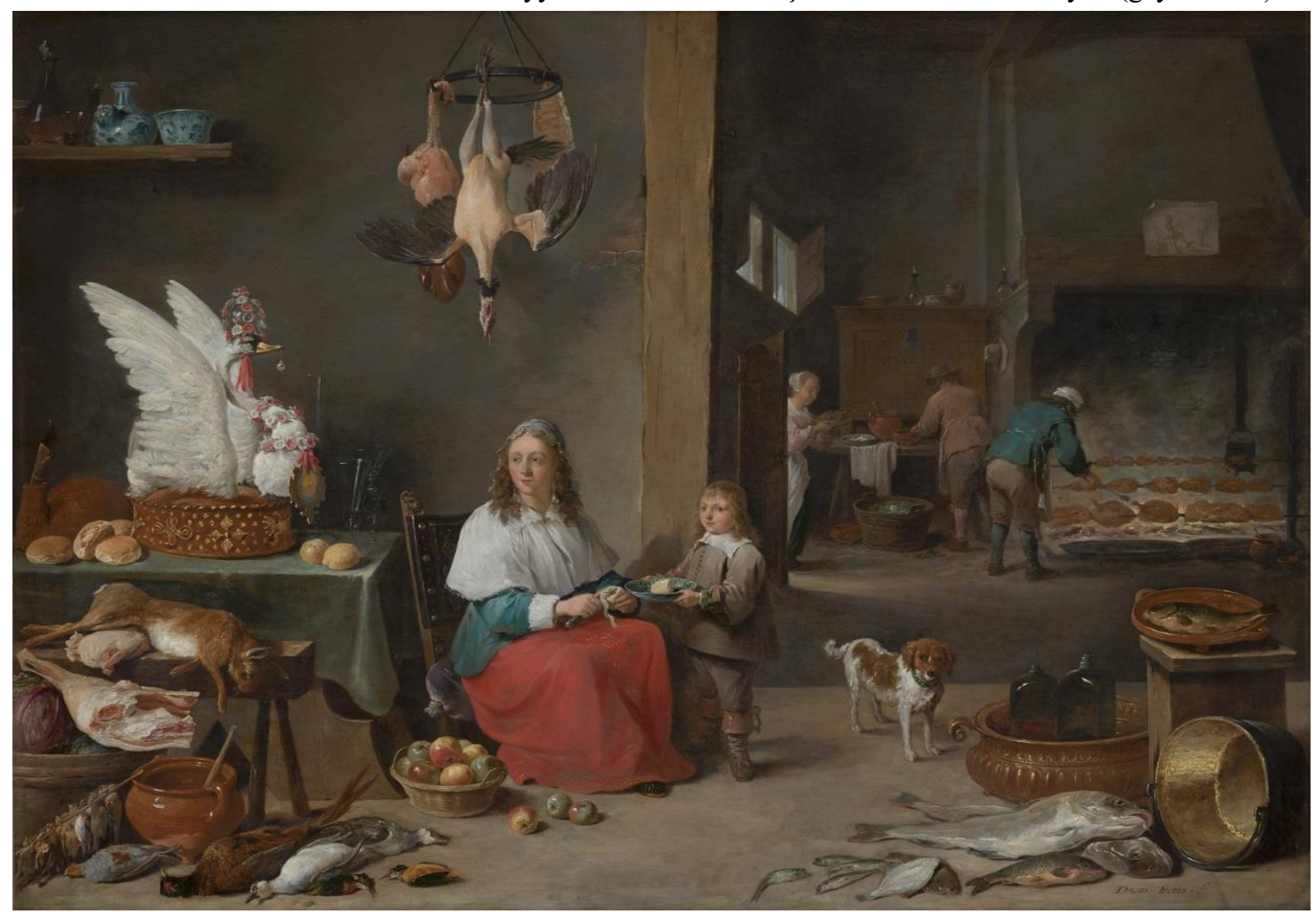

Resim 8: David Teniers the Elder, Mutfak (The Rich Kitchen), 1644, Mauritshuis, Hague.

kamusal olan ve olmayan (özel) alanlar arasındaki ayrımın mutfaklara da yansıdığını belirtmiştik. Genç David Tenier's resminde (Resim 8) bu ayrım oldukça belirgin görülmektedir. Yemek hazırlıklarının yapıldı̆̆ mutfakların yemek yeme alanı ile hiçbir bağlantısı kalmamış, mutfaklar resmi alanların tamamıyla dışında bırakılmışlardır. Sonuç olarak da Teniers'in mutfağında olduğu gibi geniş, ferah ve yapılandırılmış mutfaklar ortaya çıkmıştır (Malaguzzi, 2008:74). Teniers'in mutfağı daha önce gördüğümüz mutfak resimlerinden daha dingin bir atmosfere sahiptir. Kaslı kolları ile büyük et parçalarıyla uğraşan gürbüz kadınların yerini sandalyesinde oturarak sakince meyve soyan bir kadın figür almıştır. Bu kadın figür Teniers’in karısı Anna Bruegel, yanındaki de oğlu David'dir (İren Boynudelik ve Önel Kurt, 2018:69). Teniers'in mutfağında sağ 
arka plandaki büyük şöminede şişlere geçirilmiş etler pişirilir. Ateşteki et miktarı, ön planda yerlere taşan taze yiyeceklere, asılı kümes hayvanlarına, balıklara, meyvelere, tüketilmek üzere soğutulan içeceklere, üzerinde büyük bir kuğu süslemesi olan tarta bakılırsa bu oldukça büyük ve gösterişli bir davet olmalıdır.

18.yy'a gelindiğinde mutfaklar eziyet çekilen yerler olmaktan oldukça uzaklaşmışlardır. Horemans'ın eserinde (Resim 9) betimlediği kadın aşçı, ağır işlerle adeta güreşen öncüllerinden çok uzak bir görünüm sergilemektedir. Yakasındaki dekoratif çiçeği ve yudumladığı birasıyla halinden oldukça memnun görünen bu kadın figür izleyiciye gülümseyerek bakmaktadır. Bu resimde daha önceden mutfağa egemen olan gürbüz kadınlardan eser yoktur. Mutfak daha rahat bir çalışma alanı haline gelmiştir. Yeni ekipmanlar sayesinde aş̧̧ının daha güçlü olmasına gerek kalmamıştır. Ateşin üzerine konan demir ayaklar sayesinde pişirme kapları güvenli bir şekilde ateşin üzerinde durmaktadır. Mutfaktaki her gereç çalışanlar tarafından yönetilebilmektedir ve bunu yapmak yorucu olmaktan uzaklaşmıştır. Horemans'ın mutfağ 1 ekipmanlara kolayca ulaşılabilen, ateşin kontrol altına alındığı ve oldukça düzenli bir mutfaktır. Çalışanlar ağır bir iş yükünü zorlu koşullarda tamamlamaz, aksine işler oturularak hatta bir içki yudumlayarak görülür. Horemans'in mutfağında görülen dinginlik ön plandaki köpeğe bile sirayet etmiştir. Daha önceki mutfak sahnelerinin aksine burada betimlenen köpek bir et parçası için kedilerle kavgaya tutuşmaz. Gözü karşısındaki ölü tavukta olmakla beraber, onu çalmak için hamlede bulunmaz. Aksine sakince kıvrılıp izler (Bendiner, 2004:84).

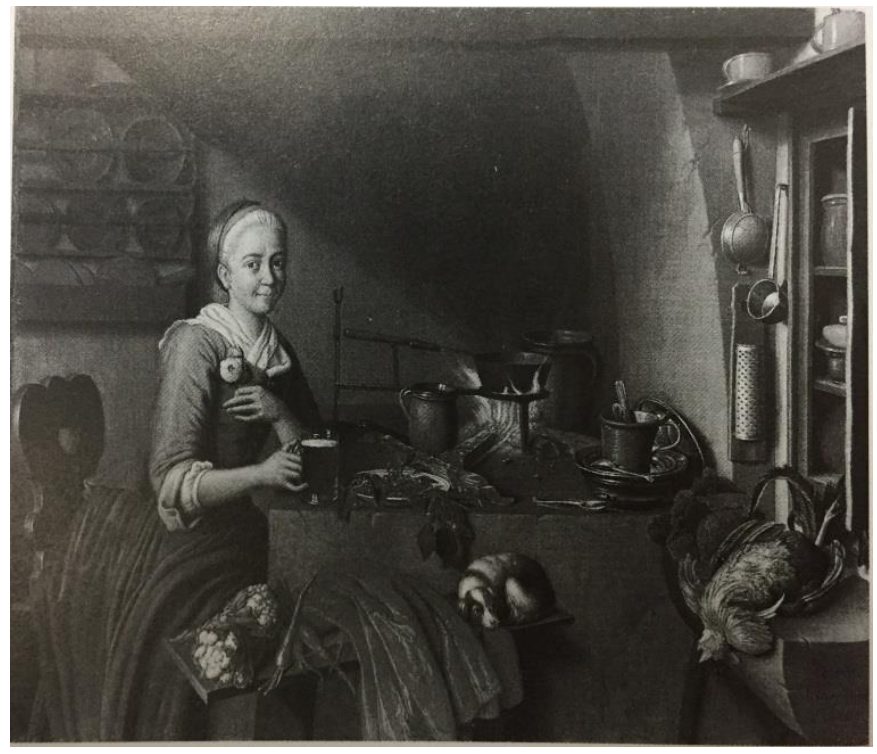

Resim 9: Pieter Jacob Horemans, The Servant, 1765, Staatsgemaldesammlungen, Munich

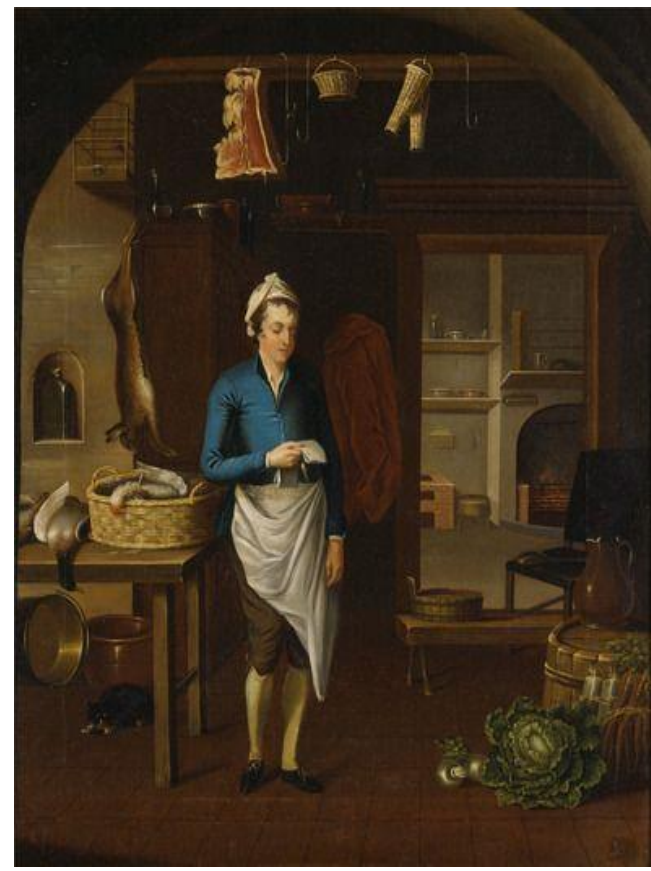

Resim 10: John Atkinson, Mutfak Sahnesi, 1771, Yale Center for British Art, New Heaven

Yine 18.yy'a ait bir mutfağın betimlendiği Atkinson'un eserinde (Resim 10) de son derece düzenli ve temiz bir mutfak görürüz. Basit bir günlük hayat resmi olan bu eserde, şık ve temiz giyimli bir aşçı elindeki sipariş listesiyle muhtemelen 1smarladıklarının gelip gelmediğini kontrol ederken betimlenmiştir. Bu mutfakta karmaşanın yerini huzur, gürültünün yerini de sessizlik almıştır (İren Boynudelik ve Önel Kurt, 2018:74).

Fransız ressam Martin Drölling'in 19.yy'ın erken dönemlerinde tasvir ettiği mutfak (Resim 11) farklı şekillerde ve ebatlarda pek çok objenin düzensiz bir şekilde bulunduğu bir mutfak örneğidir. İlk bakışta oldukça düzensiz görünen mutfak, içerisinde bulunan dekoratif kır çiçekleri, yerde oyun oynayan küçük çocuk ve gülümseyerek işlerini yapan kadınlarla sıcak ve sevimli bir ortama dönüşmüştür (Bendiner, 2004:85). 


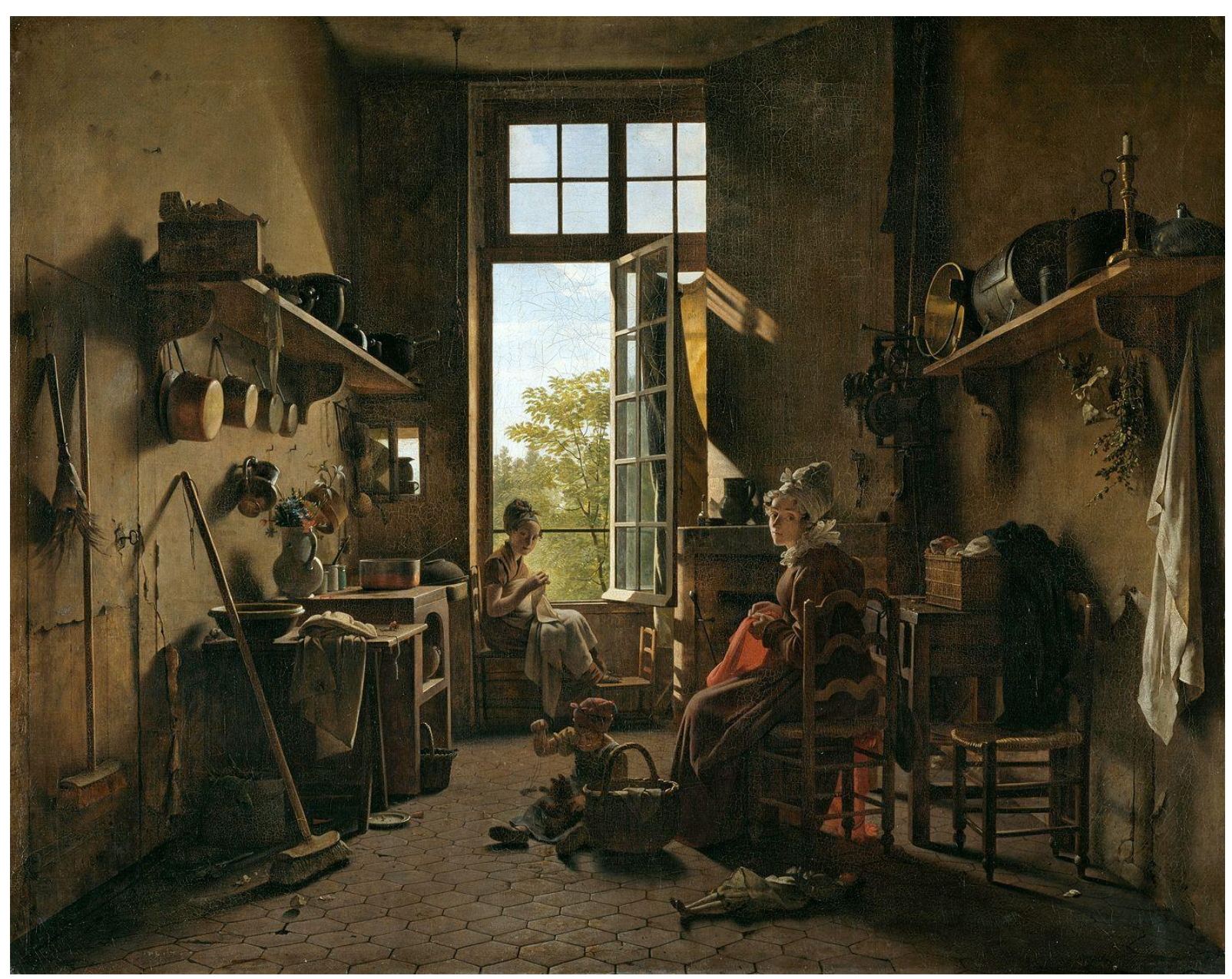

Resim 11: Martin Drölling, Interior of a Kitchen, 1815, Musee du Louvre, Paris.

19.yy'ın sonlarına gelindiğinde mutfaklar artık gurme zevklerin ortaya çıkarıldığı bir zanaat alanı haline gelmiştir. 16. ve 17.yy'daki örnekleriyle kıyaslandığında mutfakların görüntüsü oldukça değişmiştir (Resim 12). Mutfaklar artık bir mezara benzemez. Etlerin parçalanması, tüylerin yolunması veya bütün et parçalarının şişe geçirilmesi gibi kanlı ve kaba işler mutfağın dışına çıkmıştır. Ateş daha da kontrol altına alınmış, kuzineli ocaklar kullanılmaya başlanmıştır. Yapılan işler, giyilen giysiler görece daha zarif ve ince hale gelmiştir. Kaslı ve iri bir vücut gerektiren ağır işler azalmış, daha narin vücutlu, şık ve temiz giyimli aşçılar görülmeye başlanmıştır. Mutfaklarda görülen işler daha artistik bir görünüme bürünmüştür. Yemek pişirmek ve mutfakta çalışmak alt sınıfa özgü bir faaliyet olmaktan çıkmış, Vibert'in tablosunda da görüldüğü gibi mutfaklar Katolik bir din adamının bile gurme zevkler uğruna önlük giydiği daha elit mekanlar haline gelmiştir. 


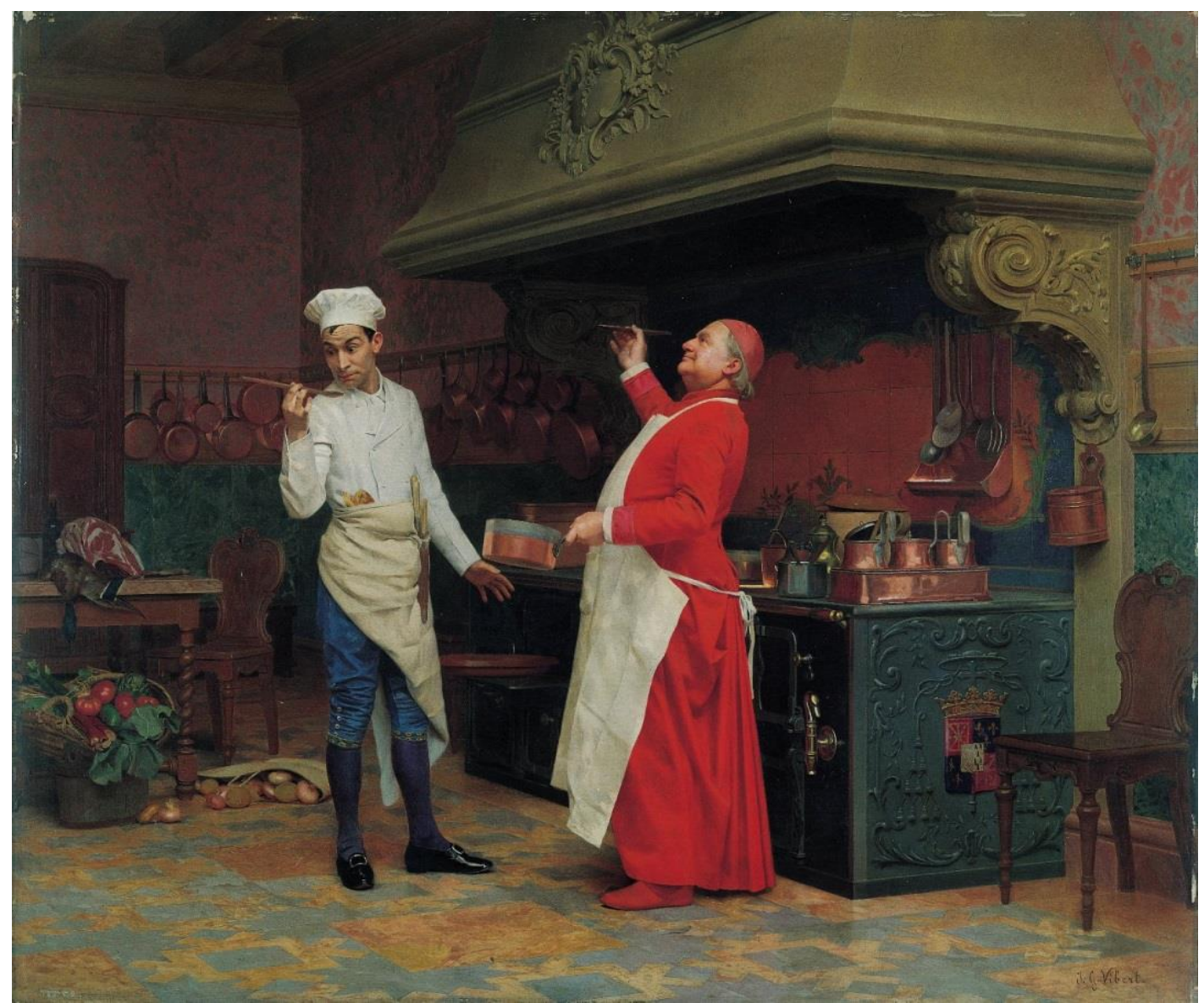

Resim 12: Jehan Georges Vibert, The Marvellous Sauce, yakl.1890, Albright-Knox Art Gallery, Buffalo, New York.

\section{SONUÇ}

İnsanlığın yaşam mücadelesindeki en önemli öğelerden biri olan ateş mutfakların tarihini başlatır. İnsan ısınmak ve avlanmak için kullandığı ateşi gıdaları pişirmek için de kullanmıştır. Aileler, soylar, klanlar ateşin etrafında bir araya gelmişler ve sosyal birliktelikleri oluşturmuşlardır. Ateş insanoğlunun yaşam şeklini ve yaşadığı mekanın yapısını yönlendirmiştir. Özellikle yerleşik yaşama geçen insan, yemek hazırlayıp yediği, ritüeller gerçekleştirdiği, uyuduğu alanları ateşin etrafında konumlandırmıştır. İnsanoğlu zamanla ateşin etrafındaki yaşamını duvarlar çekerek bölümlere ayırmıştır. Yerleşik yaşamın görüldüğü ilk topluluklarda depolar, hayvan barınakları ya da ritüel odaları gibi bölmeler görülmeye başlanmıştır (örn. Çatalhöyük, Aşıklıhöyük, Çayönü yerleşim merkezleri). Ancak ateş ve dolayısıyla mutfak yaşamsal önemini korumuş ve aile üyelerinin bir araya geldiği merkez olma görevini yüzyıllar boyunca sürdürmüştür.

Mutfaklarda önemli değişikliklerin yaşandığ 16. ve 19.yy arasındaki dönemi ele alan bu çalışma, resim sanatından örneklerle yaşanan değişikliklere 1şık tutmaya çalışmışır. Gastronomi yazınında pek çok kez ele alınan mutfak tarihini, alternatif bir yöntem kullanarak dönemine tanıklık eden resimler aracılığıyla incelemiştir. Bunu yapmaktaki temel amaç ise mutfak tarihi alanındaki yazını çeşitlendirerek katkıda bulunmaktır.

Yapılan incelemeler sonucunda 16.yy'ın erken dönemlerinde mutfakların merkezinde açık bir ateşin yandığı bir şömine bulunur. Bu ateş üzerinde kazanlar kaynatılır ya da şişte etler çevrilir. İlerleyen dönemlerde mutfağın dışına taşınacak olan pek çok iş (örn. hayvanların tüylerinin yolunması, iç organların çıkarılması, etlerin parçalanması) bu dönemde mutfağın içinde görülür. Bu dönem mutfak sahnelerinde görülen önemli bir öğe de bugün "erkek işi” olarak grupladığımız bu zorlayıcı görevlerin iri yarı, gürbüz kadınlar tarafından görülmesidir. Kaslı kolları ve al yanakları ile meşakkatli ve ağır işlerin üstesinden kolaylıkla gelen bu kadınlar resimlerin ön planında tasvir edilir (Resim 2 ve Resim 3). Kol gücüyle çalışan bu kadın aşçılar adeta birer tanrıça gibi görünseler de bu dönemin ressamları ya da yapı ustaları gibi bu kadınlar da itibarı düşük bir meslek yapmaktaydılar. Rönesans hümanistlerinin aşçılık mesleğine sağladığı itibardan henüz payını alamamış bu kadınların emeklerinin onurlu sayılabilmesi için daha çok uzun zaman (yakl. 200 yıl) gerekmektedir. Bu 
döneme ait resimlerde görülen bir diğer önemli özellik ise öndeki mutfak sahnelerinin arkasında betimlenen kutsal sahnelerdir. Örneğin Martha ve Meryem'in Evindeki İsa'nın geri planda tasvir edildiği mutfak sahnesinde (Örn. Resim 5), ön plandaki yiyecek bolluğu ile arkadaki kutsal sahne bir zitlık oluşturacak şekilde verilir. Bu alegorik anlatımın amacı kişinin dünyevi zevklere olan düşkünlüğüne dikkat çekmek ve manevi dünyayı hatırlatmaktır.

17.yy'a tarihlenen mutfak sahnelerinde yine benzer bir atmosfer görülür. Mutfağın merkezindeki şöminede yemekler pişer, raflarda servis tabakları ve tencereler asılıdır. Bu döneme ait mutfak sahnelerinde mutfakların görece daha sakin mekanlar olduğu ve yapılan işlerin de görece daha az meşakkatli hale gelmesidir. Bu dönem Avrupası'nda yemek sofraları Rönesans elit toplumu için daha büyük önem kazanır. Bu nedenle, aşçının sosyal rolü de artmış, aşçılar saray halkının değerli bir üyesi olarak görülmeye başlanmıştır. Buna rağmen, 17. ve 18. yüzyıllarda bile çok az aşçı takdir edilen bir meslek ustası konumunu elde edebilmiştir. Bu dönem resimlerinde ortaya çıkan bir diğer önemli şey şüphesiz ki yemek yeme alanlarının mutfaklardan uzaklaşmasıdır (Örn. Resim 6 ve Resim 7). Hatta bazı mutfakların evin geri kalanından tamamen ayrıldığı bile görülür (Örn. Resim 8).

Zaman içinde mutfaklar genişlemiş, kullanılan ekipmanlar artmış ve çeşitlenmiştir. Artık işler oturarak sakin bir biçimde yapılmaktadır (Örn. Resim 8 ve Resim 9). Mutfaklar artık kargaşanın hakim olduğu mekanlar değildir. İnsanların ekipmanlara daha kolay ulaştığ 1 , daha organize çalışma alanları haline gelmişlerdir (Resim 9 ve Resim 10). 18.yy'a gelindiğinde çalışanlar artık daha mutlu, daha temiz giyimlidir (Resim 12). Avrupa'da özellikle de Fransa' da aşçılık üzerine pek çok önemli ve yenilikçi eserlerin verildiği 17. yy sonları ve 18.yy başlarına denk gelen bu dönemde, mutfaklar artık tartışılmaya uygun yerler haline gelmişti. Aşçılık ise onurlu bir meslek olma yolunda ilerliyordu. Yemek yazarlığının uluslararası düzeyde kabul gören bir edebi alana dönüşmeye başlandığı bu dönemde 'gastronomi' kelimesi yükselişe geçmiş ve iyi beslenmeye ilişkin çeşitli anlayışların ebedi ve artistik bir ifadesi haline gelmiştir. Buna paralel olarak, pek çok hazırlık ve pişirme aşamasından geçen yiyeceklerin mutfaklardaki uzman çalışanlar tarafından gurme lezzetlere dönüştürülmeye başlandığı görülür.

$\mathrm{Bu}$ çalışmanın ortaya koyduğu önemli bir sonuç da günlük yaşamın vazgeçilmez bir unsuru olan mutfakların ve yemek hazırlıklarının belli sınıf için toplumsal statü göstergesi olmasıdır. Resim sanatı örneklerinde incelenen mutfaklar ve mutfak içinde tasvir edilen bolluk, farklı toplumsal kesimler tarafindan bir sosyal statü ve ekonomik gösterge halini almıştır. Yemek ve toplumsal sınıflar arasındaki ilişkiye dair veri niteliğindeki bu sonuç, gıda sosyolojisi alanında yapılan çalışmalar için yeni bir boyut oluşturmaktadır. Günümüze değin beslenme sosyolojisi üzerine yapılan çalışmalar genellikle yemeğin tüketim aşamasına yoğunlaşmıştır. Bu konular arasında 'sınıf, etnik köken ve toplumsal cinsiyet gibi faktörlerin yemek yeme deneyimleri', 'dışarıda yemek yeme olgusu', 'yemek ve kimlik' gibi başlıklar sosyoloji disiplininin oldukça ilgisini çekmiştir. Ne var ki gıdanın üretimi ve dağıtımı üzerine yapılan çalışmalar, tüketim boyutu üzerine yapılan araştırmalara oranla kısır ve eksik kalmıştır (Akarçay, 2016: 36; Beardsworth ve Keil, 2012: 86). Gıda üretim sürecinin ayarlanmasında ve mutfak hazırlıklarının örgütlenmesinde görülen eğilimler ve bu eğilimlerin tarihsel süreçteki değişimini ortaya koyan bu çalışma, gıda sosyolojisi disiplinine yeni bir araştırma alanı sunmaktadır. Nitekim çalışmada incelenen tablolar kadınların mutfak görevlerindeki rolü, mutfakta çalışmanın zaman içinde daha ince bir eylem haline gelmesi, aşçılığın daha saygın bir meslek olarak doğuşu gibi toplumsal değişimleri gözler önüne sermektedir. 


\section{KAYNAKÇA}

Akarçay, Erhan, (2016) Beslencenin Sosyolojisi - Orta Sınıf(lar)ın Yeme İçme ve Eğlence Örüntüleri. Phoenix Yayınevi, Ankara.

Akbaba, A. ve Çetinkaya, N., (2018) Gastronomi ve Yiyecek Tarihi. Detay Yayıncılık, Ankara.

Akdeniz Ay, Defne, (2017) '17. Yüzyıl Hollanda Resim Sanatında Yiyecek-İçecek Öğeleri: Portre, Tür ve Ölüdoğa Sanatından Örneklerle', Journal of Tourism and Gastronomy Studies, 5:1, s. 76-95.

Akdeniz, Defne, (2017) Resim Sanatında Gastronomi, Gece Kitaplığı, Ankara.

Barnes, D. R. ve Rose, P. G., (2002). Matters of Taste: Food and Drink in Seventeenth-Century Dutch Art and Life, Institute of History and Art / Syracuse University Press, Albany.

Beardsworth, A. ve Keil, T., Yemek Sosyolojisi: Yemek ve Toplum Çalışmasına Davet. Çev.: Abdulbaki Dede, (2012) Phoenix Yayınevi, Ankara.

Bendiner, K., (2004) Food in Painting- From the Renaissance to the Present. Reaktion Books. London.

Bober, P.P., Antikçağ ve Ortaçağda Sanat, Kültür ve Mutfak, 2.bs., çev.: Ülkün Tansel, (2014) Kitap Yayınevi, İstanbul.

Buchholz, E. L., Bühler, G., Hille, K., Kaeppele S. ve Stotland, I., Sanat. Çev.: Derya Nükhet Özer, (2012) NTV Yayınları, İstanbul.

Civitello, L., (2008) Cuisine and Culture - A History of Food and People, John Wiley \& Son, New Jersey.

Crowther, G., (2013) Eating Culture: An Anthropological Guide to Food. Ontario, University of Toronto Press, Kanada.

Delemen, İ., (2003) Antik Dönemde Beslenme, 2.bs., Ege Yayınları, İstanbul.

Farthing, S., Sanatın Tüm Öyküsü, 2.bs., çev.: Gizem Aldoğan, Firdevs Candil Çulcu, (2014) Hayalperest Yayınevi, İstanbul.

Freedman, P., Yemek- Damak Tadının Tarihi, 1.bs., çev.: Nurettin Elhüseyni, (2008) Oğlak Güzel Kitaplar, İstanbul.

Goody, Jack, Yemek, Mutfak, Sınıf - Karşılaştırmalı Sosyoloji Çalışması, 1.bs., çev.: Müge Günay Güran, (2013) Pinhan, İstanbul.

Grieco, A.J., (2009) 'Ortaçağ Sonu ve Rönesans İtalya'sında Yemek ve Toplumsal Sınıflar’, Yemek ve Kültür, Sayı 17, s. $61-71$.

Grolier, Pierrette, (2005) Fransız Mutfağı - Dünya Mutfağından Lezzetler, Dönence Basım ve Yayın Hizmetleri, İstanbul.

Gürsoy, Deniz, (2013) Yiyelim İçelim Tarihini Bilelim - Dünden Bugüne Gastronomi, Oğlak Yayıncılık ve Reklamcıllk, İstanbul.

Gürsoy, Deniz, (2014) Deniz Gürsoy’un Gastronomi Tarihi, Oğlak Yayıncılık ve Reklamcılık, İstanbul.

Gombrich, E. H., Sanatın Öyküsü, 8.bs., çev.: Erol Erduran ve Ömer Erduran, (2013) Remzi Kitabevi, İstanbul.

Holland, Mina, Yemek Atlası - Otuz Sekiz Mutfakta Dünya Turu, 1.bs, çev.: Saliha Nilüfer, (2016) Yapı Kredi Yayınları, İstanbul.

Irmscher, Günter, (1986) "Ministrae voluptatum: Stoicizing Ethics in the Market and Kitchen Scenes of Pieter Aertsen and Joachim Beuckelaer", Netherlands Quarterly for the History of Art, Vol. 16, No. 4, s. 219-232.

Işın, P. M. (2018) Avcılıktan Gurmeliğe Yemeğin Kültürel Tarihi, Yapı Kredi Yayınları, İstanbul.

İren Boynudelik, Zerrin ve Önel Kurt, Emine, (2018) Bu Resim Ne Anlatıyor? Günlük Hayat, İstanbul Bilgi Üniversitesi Yayınları, İstanbul.

Kiple, K.F., Gezgin Şölen - Gıda Küreselleşmesinin On Bin Yılı, çev.: Nurettin Elhüseyni, (2010) Yapı Kredi Yayınları, İstanbul.

Kiple, K. F. ve Ornelas, K. C., (1999). The Cambridge World History of Food, Cambridge University Press, New York.

Korkutata, Abdulmenaf, (2013) Fransız Mutfağı s. 33-51, içinde Uluslararası Gastronomi - Temel Özellikler, Örnek Menüler ve Reçeteler, (Editör: Mehmet Sarışık), Detay Yayıncılık, Ankara.

Larousse Gastronomique: The World's Greatest Culinary Encyclopedia, Completely Revised and Updated

Malaguzzi, S., (2008) Food and Feasting in Art, Getty Publications, California.

Montanari, M. Avrupa'da Yemeğin Tarihi - Avrupa'yı Kurmak, çev.: Mesut Önen ve Biranda Hinginar, (1995) Afa Yayıncılık A.Ş., İstanbul.

Picq, P., Sagart, L., Dehaene, G. ve Lestienne, C., Dilin En Güzel Tarihi, 3.bs, çev: Sema Rifat, (2016) Türkiye İş Bankası Kültür Yayınları, İstanbul.

Riley, Gillian, (2015) Food in Art -From Prehistory to the Renaissance, Reaktion Books, Londra.

Soyer, A., (1977) The Pantropheon: or a History of Food and its Preparation in Ancient Times, Paddington Press, New York.

Standage, T., İnsanlığın Yeme Tarihi, çev.:Gencer Çakır, (2016) Maya Kitap, İstanbul.

Sullivan, Margaret A., (1999) “Aertsen's Kitchen and Market Scenes: Audience and Innovation in Northern Art”, The Art Bulletin, 81:2,s. 236-266

Tez, Zeki, (2012) Lezzetin Tarihi, Hayy Kitap, İstanbul.

Toussaint-Samat, M., A History of Food, 2.bs, çev.: Anthea Bell, (1992) Blackwell Reference, Cambridge.

Woolgar, C.M., (2008) Şölen ve Perhiz - Ortaçağ Avrupa'sında Yemek ve Damak Tadı, içinde Freedman, P., YemekDamak Tadının Tarihi, 1.bs., çev.: Nurettin Elhüseyni, (2008) Oğlak Güzel Kitaplar, İstanbul. 